\title{
A new treefrog from Cordillera del Cóndor with comments on the biogeographic affinity between Cordillera del Cóndor and the Guianan Tepuis (Anura, Hylidae, Hyloscirtus)
}

\author{
Santiago R. Ron', Marcel A. Caminer', Andrea Varela-Jaramillo', \\ Diego Almeida-Reinoso'
}

I Museo de Zoología, Escuela de Biología, Pontificia Universidad Católica del Ecuador, Av. 12 de Octubre y Roca, Aptdo. 17-01-2184, Quito, Ecuador

Corresponding author: Santiago R. Ron (santiago.r.ron@gmail.com)

Academic editor:Angelica Crottini | Received22March 2018|Accepted28September 2018| Published 19December 2018

http://zoobank.org/17A46360-8038-4385-A995-1168357B08A3

Citation: Ron SR, Caminer MA, Varela-Jaramillo A, Almeida-Reinoso D (2018) A new treefrog from Cordillera del Cóndor with comments on the biogeographic affinity between Cordillera del Cóndor and the Guianan Tepuis (Anura, Hylidae, Hyloscirtus). ZooKeys 809: 97-124. https://doi.org/10.3897/zookeys.809.25207

\begin{abstract}
The Hyloscirtus larinopygion group is a clade of 16 species of large hylids that inhabit cascading Andean streams. They have brown coloration that, in most species, contrasts with bright marks. Herein morphological and genetic evidence is used to describe a new species of the group from Cordillera del Cóndor, a sub-Andean mountain chain that has phytogeographic affinities with the Guianan Tepuis. The new species is characterized by dark-brown coloration with contrasting bright orange flecks and by the presence of an enlarged and curved prepollex protruding as a spine. The new species is closely related to $H$. tapichalaca and an undescribed species from the southern Andes of Ecuador. The genetic distance between $H$. hillisi sp. n. and its closest relative, $H$. tapichalaca, is $2.9 \%$ (gene $16 \mathrm{~S} \mathrm{mtDNA}$ ). Our phylogeny and a review of recently published phylogenies show that amphibians from Cordillera del Cóndor have close relationships with either Andean or Amazonian species. Amphibians do not show the Condor-Guianan Tepuis biogeographic link that has been documented in plants.
\end{abstract}

\section{Keywords}

Biodiversity, Colomascirtus, Ecuador, H. larinopygion group, Peru, prepollical spine, phylogeny

Copyright Santiago R. Ron et al. This is an open access article distributed under the terms of the Creative Commons Attribution License (CC BY 4.0), which permits unrestricted use, distribution, and reproduction in any medium, provided the original author and source are credited. 


\section{Introduction}

Hyloscirtus Peters 1882, is a genus of 37 species of treefrogs distributed from Costa Rica to the Andes of Bolivia, Colombia, Ecuador, Peru, and Venezuela (AmphibiaWeb 2018; Frost 2018). They reproduce along streams and share, as a synapomorphy, the presence of wide lateral fringes on fingers and toes (Faivovich et al. 2005 but see Coloma et al. 2012). A well-supported clade within Hyloscirtus is the Hyloscirtus larinopygion species group (Almendáriz et al. 2014; Coloma et al. 2012; Duellman and Hillis 1990; RiveraCorrea et al. 2016). It is composed of 16 species characterized by large size (SVL $<60$ $\mathrm{mm}$ ) and gray or brown coloration that in many species contrast with bright marks. Species of this group were transferred to the genus Colomascirtus by Duellman et al. (2016). A recent phylogeny showed that the recognition of Colomascirtus rendered Hyloscirtus paraphyletic (Rojas-Runjaic et al. 2018). To maintain taxonomic stability, Colomascirtus was synonymized under Hyloscirtus by Rojas-Runjaic et al. (2018).

The Hyloscirtus larinopygion group is composed of two well-supported clades that replace each other latitudinally with a small area of sympatry in central Ecuador (Almendáriz et al. 2014a). The northern clade is distributed in the Andes of central and northern Ecuador and southern Colombia; the southern clade is distributed in the eastern Andean slopes of central and southern Ecuador and northern Peru (Rivera-Correa et al. 2016). The southern clade is composed of three species: $H$. condor Almendáriz et al. 2014a, H. tapichalaca (Kizirian et al. 2003), and an undescribed species previously reported as H. lindae (Almendáriz et al. 2014a). Hyloscirtus diabolus Rivera-Correa et al. 2016 is also a putative member of this clade (Rivera-Correa et al. 2016). The four species differ from species in the northern clade by having an enlarged prepollex with the shape of a spine that protrudes below the thumb (Almendáriz et al. 2014; Rivera-Correa et al. 2016). Recent fieldwork in Cordillera del Cóndor by a field team from the Museum of Zoology, Pontificia Universidad Católica del Ecuador, resulted in the discovery of an undescribed species of the southern clade which also shares a spine-shaped prepollex. Cordillera del Cóndor is a sub-Andean mountain chain with phytogeographic affinities to the Tepuis in the Guiana Region (e.g., Neill 2005). Herein we present morphological and genetic evidence to describe the new species and provide a new phylogeny for the genus Hyloscirtus. We also review recent amphibian phylogenies to explore the existence of biogeographic links between Cordillera del Cóndor and the Guianan Tepuis.

\section{Materials and methods}

\section{DNA extraction, amplification, and sequencing}

DNA was extracted from muscle or liver tissue preserved in $95 \%$ alcohol following standard phenol-chloroform extraction protocols (Sambrook et al. 1989). Standard polymerase chain reaction (PCR) was performed to amplify two mitochondrial genes (12S rRNA + tRNA $^{\text {Val }}$ and 16S rRNA), using primers listed in Goebel et al. (1999), Heinicke et al. 
(2007), Hedges et al. (2008), and Heinicke et al. (2009) under standard protocols. PCR products were sequenced in both directions by Macrogen (Macrogen Inc., Seoul, Korea).

Sequences were edited and assembled with Geneious 10.2.3 software (Gene Matters Corp, Kearse et al. 2012). The obtained sequences were compared with those available in GenBank (http://www.ncbi.nlm.nih.gov/genbank/) for the Hyloscirtus larinopygion and bogotensis groups (published by Almendáriz et al. 2014; Coloma et al. 2012; Darst and Cannatella 2004; Elmer and Cannatella 2008; Faivovich et al. 2004; Faivovich et al. 2005; Guayasamin et al. 2015; Rojas-Runjaic et al. 2018; Wiens et al. 2005; Wiens et al. 2006) (Table 1). For the outgroup we added sequences of Aplastodiscus weygoldti, Bokermannohyla circumdata, Boana crepitans, B. lundii, B. marianitae, B. riojana, Itapotihyla langsdorfi, Myersiohyla kanaima, and Pseudacris nigrita.

Sequences were aligned using the Geneious extension MAFFT Multiple Alignment with the algorithm LINS-I (Katoh and Standley 2013). Alignments were imported into Mesquite (version 3.04; Maddison and Maddison 2018) for final visual adjustments. The final matrix included 2497 characters. The best partition strategy and best-fit model of nucleotide evolution for our data were obtained in PartitionFinder v.2.1.1 (Lanfear et al. 2012) under the corrected Akaike Information Criterion (AICc).

\section{Phylogeny}

Phylogenetic relationships were inferred using maximum-likelihood and Bayesian inference. Maximum likelihood analysis were conducted with GARLI 2.0 (Zwickl 2006) using default values, except for the number of generations without topology improvement required for termination (genthreshfortopoterm $=30000$ ) and the maximum number of generations to run and maximum search time (stopgen and stoptime $=5000000)$. A total of 40 independent searches were run, 20 started from random trees (streefname = random) and 20 from stepwise addition trees (streefname $=$ stepwise). Likelihood values of the 40 searches were within 0.1 likelihood units of each other indicating that all searches converged on similar optimal trees. Support was assessed using 200 bootstrap pseudoreplicates. Bayesian phylogenetic analyses were carried out in MrBayes 3.2.6 (Ronquist et al. 2012). We made four parallel runs of the Metropolis-coupled Monte Carlo Markov for 20 million generations. Each run had five chains, sampled every 1000 generations and with a temperature of 0.1 . Convergence into a stationary distribution was measured with software Tracer version 1.4 (Rambaut and Drummond 2007). The search was finished when the average standard deviations of split frequencies was $<0.05$ between runs and ESS values were $>200$ for all parameters. The consensus tree was generated after discarding $10 \%$ of the initial generations as burn-in. Bayesian analyses were carried out at Cipres Science Gateway (available at https//www.phylo.org; Miller et al. 2010).

Pairwise genetic distances between-species (uncorrected- $p$ ) were calculated with MEGA 5 (Tamura et al. 2011) for genes 16S (886 bp) and 12S (773 bp). Genetic distances for gene $16 \mathrm{~S}$ are the most widely used standard to identify candidate species (e.g., Coloma et al. 2012; Fouquet et al. 2007; Janzen and Hallwachs 2011; Vieites et al. 2009). 
Table I. Genbank accession numbers for DNA sequences included in the phylogenetic analysis.

\begin{tabular}{|c|c|c|c|c|}
\hline \multirow{2}{*}{ Species } & \multirow{2}{*}{ Museum Number } & \multicolumn{2}{|c|}{ GenBank Accession Number } & \multirow{2}{*}{ Source } \\
\hline & & $12 S$ & $16 S$ & \\
\hline \multirow{2}{*}{ Hyloscirtus alytolylax } & QCAZ 24376 & JX155799 & JX155826 & Coloma et al. 2012 \\
\hline & QCAZ 24377 & JX155798 & JX155825 & Coloma et al. 2012 \\
\hline \multirow{2}{*}{ H. armatus } & KU 173222 & AY819423 & - & Wiens et al. 2005 \\
\hline & AMNH 165163 & AY549321 & AY549321 & Faivovich et al. 2004 \\
\hline H. callipeza & UIS-A 5947 & MG596780 & MG596780 & Rojas-Runjaic et al. 2018 \\
\hline H. charazani & AMNH 165132 & AY843618 & AY843618 & Faivovich et al. 2005 \\
\hline \multirow{2}{*}{ H. colymba } & SIU 6926 & DQ380353 & - & Wiens et al. 2006 \\
\hline & SIUC H-7079 & AY843620 & AY843620 & Faivovich et al. 2005 \\
\hline \multirow{2}{*}{ H. condor } & MEPN 14754 & KF756939 & KF756939 & Almendáriz et al. 2014a \\
\hline & MEPN 14758 & KF756938 & KF756938 & Almendáriz et al. 2014a \\
\hline \multirow{3}{*}{ H. criptico } & QCAZ 43421 & JX155812 & JX155839 & Coloma et al. 2012 \\
\hline & QCAZ 43422 & JX155814 & JX155841 & Coloma et al. 2012 \\
\hline & QCAZ 45466 & JX155813 & JX155840 & Coloma et al. 2012 \\
\hline \multirow{5}{*}{ H. hillisi sp. n. } & QCAZ 68646 & MH883792 & MH883796 & This study \\
\hline & QCAZ 68647 & - & MH883797 & This study \\
\hline & QCAZ 68648 & MH883793 & MH883798 & This study \\
\hline & QCAZ 68649 & MH883794 & MH883799 & This study \\
\hline & QCAZ 68651 & MH883795 & MH883800 & This study \\
\hline \multirow{3}{*}{ H. jahni } & MHNLS 20318 & MG596776 & MG596776 & Rojas-Runjaic et al. 2018 \\
\hline & MHNLS 20319 & MG596777 & MG596777 & Rojas-Runjaic et al. 2018 \\
\hline & MHNLS 20324 & MG596779 & MG596779 & Rojas-Runjaic et al. 2018 \\
\hline \multirow{3}{*}{ H. japreria } & MHNLS 18888 & MG596766 & MG596766 & Rojas-Runjaic et al. 2018 \\
\hline & MHNLS 19235 & MG596769 & MG596769 & Rojas-Runjaic et al. 2018 \\
\hline & UIS-A 5496 & MG596770 & MG596770 & Rojas-Runjaic et al. 2018 \\
\hline \multirow{2}{*}{ H. larinopygion } & QCAZ 41826 & JX155817 & JX155844 & Coloma et al. 2012 \\
\hline & QCAZ 45462 & JX155818 & JX155845 & Coloma et al. 2012 \\
\hline \multirow{3}{*}{ H. lascinius } & KU 181086 & DQ380359 & - & Wiens et al. 2006 \\
\hline & MHNLS 19163 & MG596762 & MG596762 & Rojas-Runjaic et al. 2018 \\
\hline & MHNLS 19164 & MG596763 & MG596763 & Rojas-Runjaic et al. 2018 \\
\hline \multirow{4}{*}{ H. lindae } & QCAZ 41232 & JX155821 & JX155848 & Coloma et al. 2012 \\
\hline & QCAZ 45342 & JX155824 & JX155851 & Coloma et al. 2012 \\
\hline & QCAZ 45346 & JX155822 & JX155849 & Coloma et al. 2012 \\
\hline & QCAZ 45463 & JX155823 & JX155850 & Coloma et al. 2012 \\
\hline H. mashpi & MZUTI 614 & KT279526 & KT279511 & Guayasamin et al. 2015 \\
\hline \multirow{2}{*}{ H. pacha } & KU 202760 & AY326057 & AY326057 & Darst and Cannatella 2004 \\
\hline & WED 53493 & AY326057 & AY326057 & Darst and Cannatella 2004 \\
\hline \multirow{2}{*}{ H. palmeri } & MZUTI 608 & KT279549 & KT279520 & Guayasamin et al. 2015 \\
\hline & SIUC H-6924 & AY843650 & AY843650 & Faivovich et al. 2005 \\
\hline \multirow{3}{*}{ H. pantostictus } & QCAZ 45435 & JX155820 & JX155847 & Coloma et al. 2012 \\
\hline & QCAZ 45438 & JX155819 & JX155846 & Coloma et al. 2012 \\
\hline & KU 202732 & AY326052 & - & Darst and Cannatella 2004 \\
\hline & QCAZ 23938 & JX155800 & JX155827 & Coloma et al. 2012 \\
\hline & QCAZ 32271 & JX155802 & JX155829 & Coloma et al. 2012 \\
\hline & QCAZ 41032 & JX155801 & JX155828 & Coloma et al. 2012 \\
\hline$H$,hellograthe & KU 212119 & DQ380369 & - & Wiens et al. 2006 \\
\hline H. phyllognathus & MHNLS 20321 & MG596772 & MG596772 & Rojas-Runjaic et al. 2018 \\
\hline & MHNLS 20325 & MG596774 & MG596774 & Rojas-Runjaic et al. 2018 \\
\hline & QCAZ 42165 & JX155806 & JX155833 & Coloma et al. 2012 \\
\hline & QCAZ 43654 & JX155807 & JX155834 & Coloma et al. 2012 \\
\hline camolaimus & QCAZ 27049 & JX155808 & JX155835 & Coloma et al. 2012 \\
\hline H. psarolaimus & QCAZ 46095 & JX155809 & JX155836 & Coloma et al. 2012 \\
\hline & QCAZ 46030 & JX155804 & JX155831 & Coloma et al. 2012 \\
\hline H. ptychodactylus & QCAZ 46031 & JX155805 & JX155832 & Coloma et al. 2012 \\
\hline H. simmonsi & KU 181167 & DQ380376 & - & Wiens et al. 2006 \\
\hline$H$ staufferorum & QCAZ 45962 & JX155816 & JX155843 & Coloma et al. 2012 \\
\hline H. staufferorum & QCAZ 45967 & JX155815 & JX155842 & Coloma et al. 2012 \\
\hline
\end{tabular}




\begin{tabular}{lcccc}
\hline \multicolumn{1}{c}{ Species } & Museum Number & GenBank Accession Number & Source \\
& & 12S & 16S & Coloma et al. 2012 \\
H. tapichalaca & QCAZ 15083 & JX155803 & JX155830 & Faivovich et al. 2004 \\
& QCAZ 16704 & AY563625 & AY563625 & Coloma et al. 2012 \\
H. tigrinus & QCAZ 31550 & JX155811 & JX155838 & Coloma et al. 2012 \\
& QCAZ 41351 & JX155810 & JX155837 & Guayasamin et al. 2015 \\
Hyloscirtus sp. & MZUTI 3262 & KT279503 & KT279544 & Wiens et al. 2006 \\
\hline
\end{tabular}

\section{Morphology}

Specimens of the new species were compared to published descriptions and alcoholpreserved specimens of the Hyloscirtus larinopygion group from Museo de Zoología at Pontificia Universidad Católica del Ecuador, Quito (QCAZ). Examined specimens are listed as Appendix 1. Webbing formulae of hand and foot follow Savage and Heyer (1967) as modified by Myers and Duellman (1982). Morphological measurements were taken with digital calipers $( \pm 0.01 \mathrm{~mm})$ from specimens fixed in $10 \%$ formalin and preserved in $70 \%$ ethanol according to the methodology described in Duellman (1970). Measurements are: SVL (snout-vent length); HL (head length); HW (head width); ED (eye diameter); TD (tympanum diameter); TL (tibia length); FEL (femur length); and FL (foot length). Sex was determined by direct examination of gonads.

We also compared qualitative morphological characters between the new species and its closest relatives. Six characters were evaluated: (1) dorsal coloration; (2) ventral coloration; (3) marks on flanks and hidden surfaces of thighs; (4) iris coloration; (5) prepollex condition; and (6) in life, webbing coloration. Life coloration was obtained from color photographs.

\section{Results}

\section{Phylogeny and genetic distances}

According to PartitionFinder, the best partition strategy consisted of two partitions under model GTR + I + G. Maximum likelihood and Bayesian inference analyses resulted in similar topologies. Four species groups within Hyloscirtus (H. jahni, H. bogotensis, $H$. armatus, and $H$. larinopygion group) were recovered with strong support (posterior probability, $\mathrm{pp}=1.0$ and bootstrap $=100)$ in both analysis (Figure 1). However, phylogenetic relationships among these groups were weakly supported ( $\mathrm{pp}<0.71$ and bootstrap < 50), as previously reported (Almendáriz et al. 2014; Coloma et al. 2012; Guayasamin et al. 2015; Rojas-Runjaic et al. 2018). The only exception was the strong support found for the clade $H$. armatus group $+H$. larinopygion group found in the Bayessian analysis ( $\mathrm{pp}=0.99$ ). The phylogeny shows Hyloscirtus hillisi sp. n. sister to Hyloscirtus sp. + H. tapichaca. Hyloscirtus sp. (KU 202728) is an undescribed species previously referred as "H. lindae" (Almendáriz et al. 2014; Duellman and Hillis 1990). 


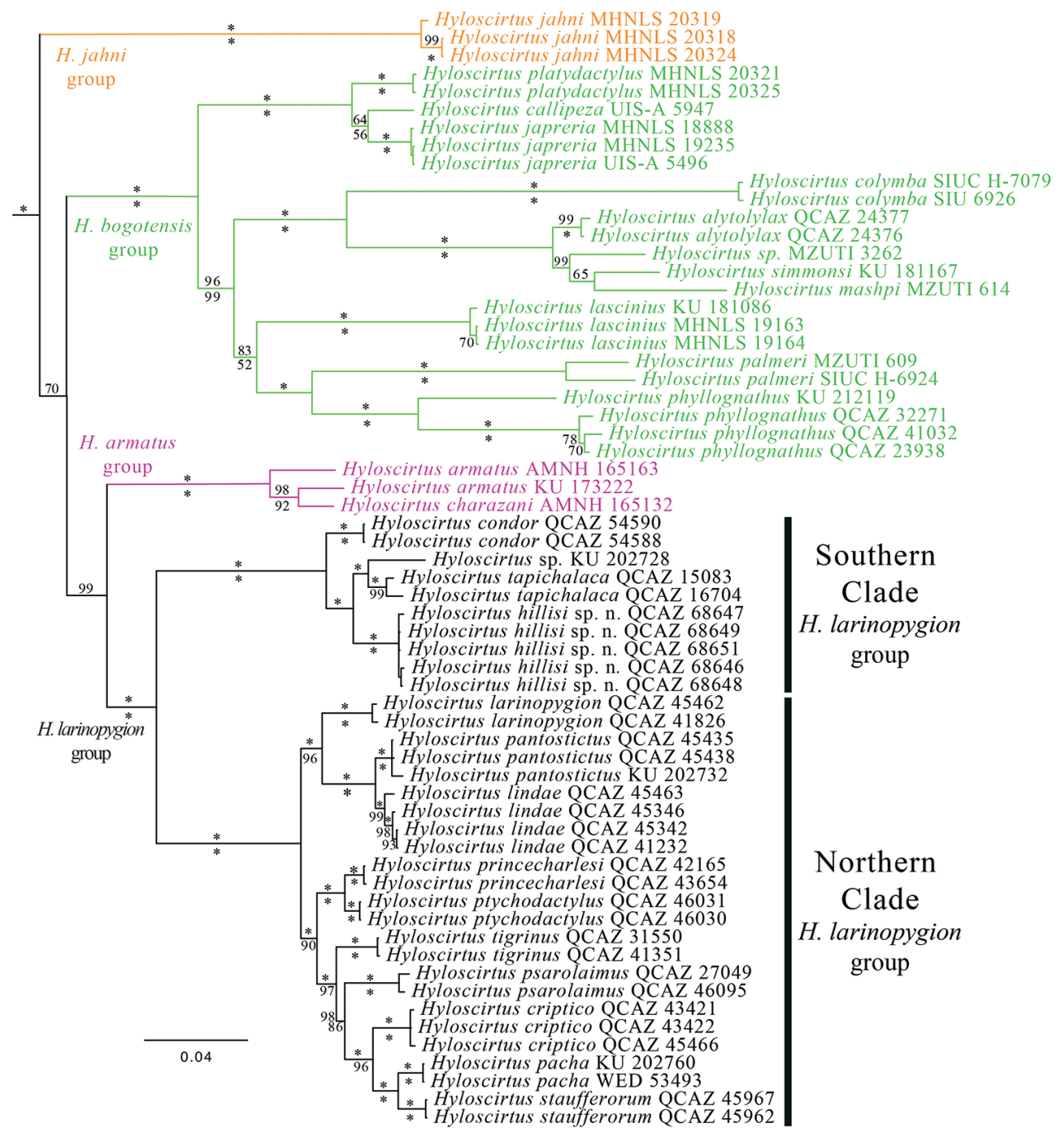

Figure I. Strict consensus tree of Hyloscirtus species inferred with Bayesian inference. Museum numbers are shown for each sample. Bayesian posterior probabilities $(\mathrm{pp} \times 100)$ are shown above the branches and bootstrap values below. Values of $100 \%$ are represented by an asterisk. Missing values indicate weakly supported nodes (pp and bootstrap < 50). Outgroup species are not shown. For locality data see Table 1 and Appendix 1.

Hyloscirtus condor is sister to a clade conformed by these three species. All together form a strongly supported clade distributed in the eastern slopes of the Andes of central and southern Ecuador and northern Peru (Southern Clade; Figs. 1, 2). The Southern Clade is sister to a clade distributed to the north and confirmed by the remaining species of the Hyloscirtus larinopygion group (Northern Clade; Figs. 1, 3). The Northern and Southern clades have a narrow zone of sympatry in central Ecuador (Figure 2).

Genetic distances between the new species and its closest relatives are characteristic of interspecific distances for the $H$. larinopygion group. For gene $12 \mathrm{~S}$, distances with 


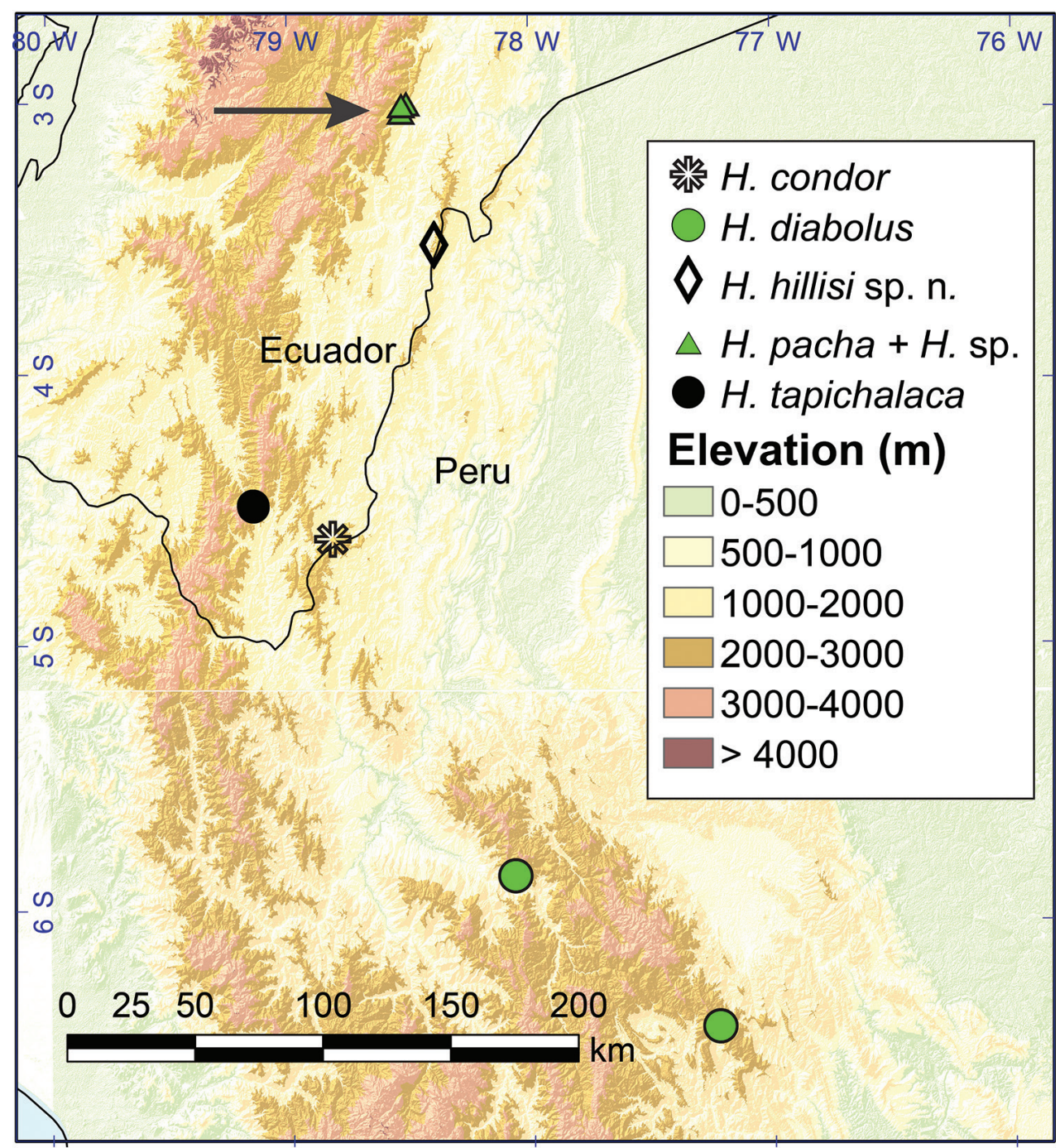

Figure 2. Records of the Southern Clade of the Hyloscirtus larinopygion group. Locality data were obtained from specimens deposited at Museo de Zoología, Pontificia Universidad Católica del Ecuador (QCAZ), Duellman and Hillis (1990), Almendáriz et al. (2014a), and Rivera-Correa et al. (2016). The arrow indicates the locality where the Northern and Southern clades are sympatric. See text for details.

H. tapichalaca are 0.031 to 0.038 and with $H$. sp. (KU 202728) are 0.031 to 0.033 . These distances are higher than those observed for the same gene between $H$. pacha and $H$. staufferorum (0.014-0.018), $H$. princecharlesi and $H$. ptychodactylus $(0.004-0.020)$ and $H$. criptico and H. psarolaimus (0.022-0.026; Almendáriz et al. 2014). Genetic distances for gene 16S range from 0.029 and 0.040 (Table 2). The genetic divergence between $H$. hillisi sp. n. and its closest relatives and its unique morphology indicates that it is a new species that we describe below. 


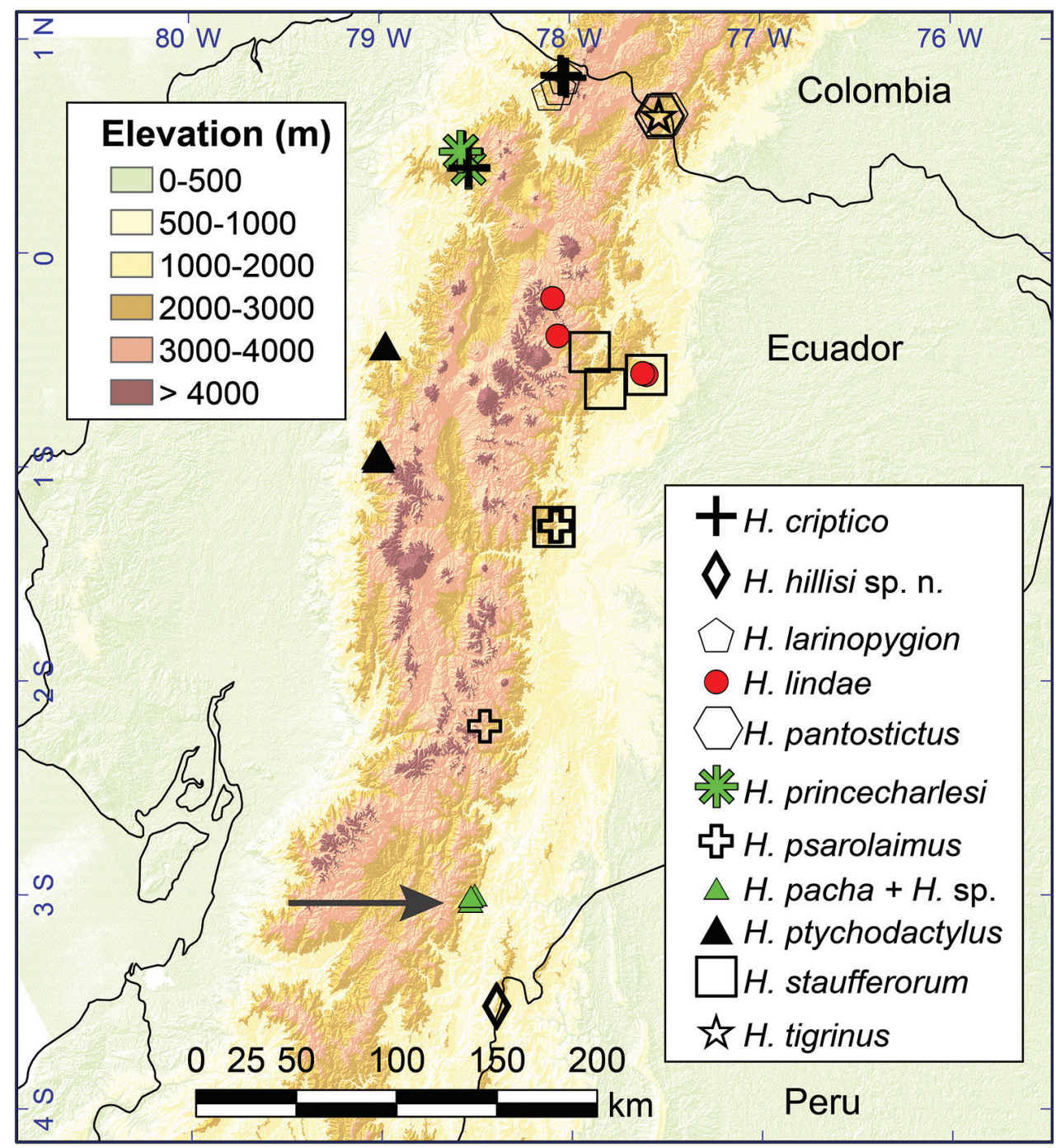

Figure 3. Records of the Northern Clade of the Hyloscirtus larinopygion group. Locality data were obtained from specimens deposited at Museo de Zoología, Pontificia Universidad Católica del Ecuador (QCAZ) and Duellman and Hillis (1990). The arrow indicates the locality where the Northern and Southern clades are sympatric. See text for details.

Table 2. Pairwise genetic distances (uncorrected- $p$ ) between Hyloscirtus hillisi sp. n. and its closest relatives, based on sequences of $16 \mathrm{~S} \mathrm{mtDNA}$. Mean and \pm standard deviation are given with range in parentheses. Diagonal values are intraspecific distances.

\begin{tabular}{lccc}
\hline & H. hillisi sp. n. $(\boldsymbol{n}=\mathbf{5})$ & H. tapichalaca $(\boldsymbol{n}=\mathbf{2})$ & H. condor $(\boldsymbol{n}=\mathbf{2})$ \\
\hline H. hillisi sp. n. & $0.001 \pm 0.0007(0-0.002)$ & - & - \\
H. tapichalaca & $0.029 \pm 0.0005(0.029-0.030)$ & 0.009 & - \\
H. condor & $0.04 \pm 0.0005(0.039-0.040)$ & $0.041 \pm 0.002(0.039-0.043)$ & 0 \\
\hline
\end{tabular}




\section{Hyloscirtus hillisi sp. $\mathrm{n}$.}

http://zoobank.org/95C54DD9-297E-471D-8E5F-2B96BE740147

Holotype. QCAZ 68649 (Figs. 5-7), field no. SC 59176, adult female from Ecuador, Provincia Morona Santiago, Caverns-cascade trail, Reserva Biológica El Quimi, on the slopes of flat-topped mountain on the eastern side of the Río Quimi valley (3.5190S, 78.3788W), $2128 \mathrm{~m}$ above sea level, collected by Diego Almeida, Darwin Núñez, Kunam Nucirquia, Alex Achig, and Ricardo Gavilanes on 8 July 2017.

Paratopotypes. QCAZ 68646, 72549 subadult females, 68651-54, 72552, tadpoles, 69001, metamorphs, 72550, 72553, adult males, 2112-2134 m of elevation. Collected on 7-14 July 2017 and 12-19 April 2018 by Diego Almeida, Darwin Núńez, Kunam Nucirquia, Alex Achig, Ricardo Gavilanes, and María del Mar Moretta.

Paratypes. All specimens from Reserva Biológica el Quimi, eastern side of the Río Quimi valley, Provincia Morona Santiago, Ecuador. Base camp surroundings, near Río Cristalino (3.5183S, 78.3914W), 1992 m, QCAZ 68647, juvenile, 68648, 68650, metamorphs, 68655-56, 71182, tadpoles collected on 4, 8-9 July 2017; second plateau, near limestone cave (3.5189S, 78.3815W), $2121 \mathrm{~m}$, QCAZ 72551, adult male, collected on 19 April 2018. Collected by Diego Almeida, Darwin Núñez, Kunam Nucirquia, Alex Achig, and Ricardo Gavilanes.

Diagnosis. The diagnosis and comparisons are based on one adult female, three adult males, and two subadult females. The new species is diagnosed by the following characters: mean SVL $70.3 \mathrm{~mm}$ in adult males (range 66.7-72.3; $\mathrm{n}=3$ ), $65.8 \mathrm{~mm}$ in one adult female; vomerine odontophores conic-shaped with a gap medially, each process with three to five prominent teeth; supracloacal flap ill-defined; supratympanic fold present; finger webbing formula: I basal II2-3 III $2 \frac{1}{2}-2 \mathrm{IV}$, toe webbing formula: I2-2II $1^{+}-2^{+} \mathrm{III} 1 \frac{1}{2}-2 \frac{1}{2} \mathrm{IV} 2 \frac{1}{2}-1^{+} \mathrm{V}$; forelimbs hypertrophied in males; enlarged and curved prepollex protruding as a spine in both sexes; fleshy calcar absent; dorsum, flanks, and dorsal areas of limbs dark grayish brown with tiny orange marks varying from abundant to sparse; venter dark grayish brown; iris bronze or yellowish with dark brown reticulation.

Comparisons. Hyloscirtus hillisi is most similar to $H$. condor, $H$. diabolus, and $H$. tapichalaca (Figure 4). They share the presence of an enlarged claw-like prepollex. Hyloscirtus condor differs in ventral coloration (light gray to light salmon in $H$. condor vs. dark brown in $H$. hillisi) and dorsal coloration (brown dorsum with diffuse yellow speckling in $H$. condor vs. dark brown dorsum with contrasting orange round marks in $H$. hillisi). Hyloscirtus diabolus differs from $H$. hillisi by having a red iris (bronze or yellowish with brown reticulations in $H$. hillisi) and a fleshy calcar (calcar absent in H. hillisi; Rivera-Correa et al. 2016). Hyloscirtus tapichalaca differs from $H$. hillisi by having a brown dorsum without orange marks (orange marks present in H. hillisi) and white disks on fingers and toes (disks are dark brown in $H$. hillisi). The remaining species of the H. larinopygion group lack the enlarged claw-like prepollex (Ardila-Robayo et al. 1993; Mueses-Cisneros and Anganoy-Criollo 2008; Mueses-Cisneros and Perdomo-Castillo 2011; Ruiz-Carranza and Lynch 1982; Rivera-Correa et al. 2016). 

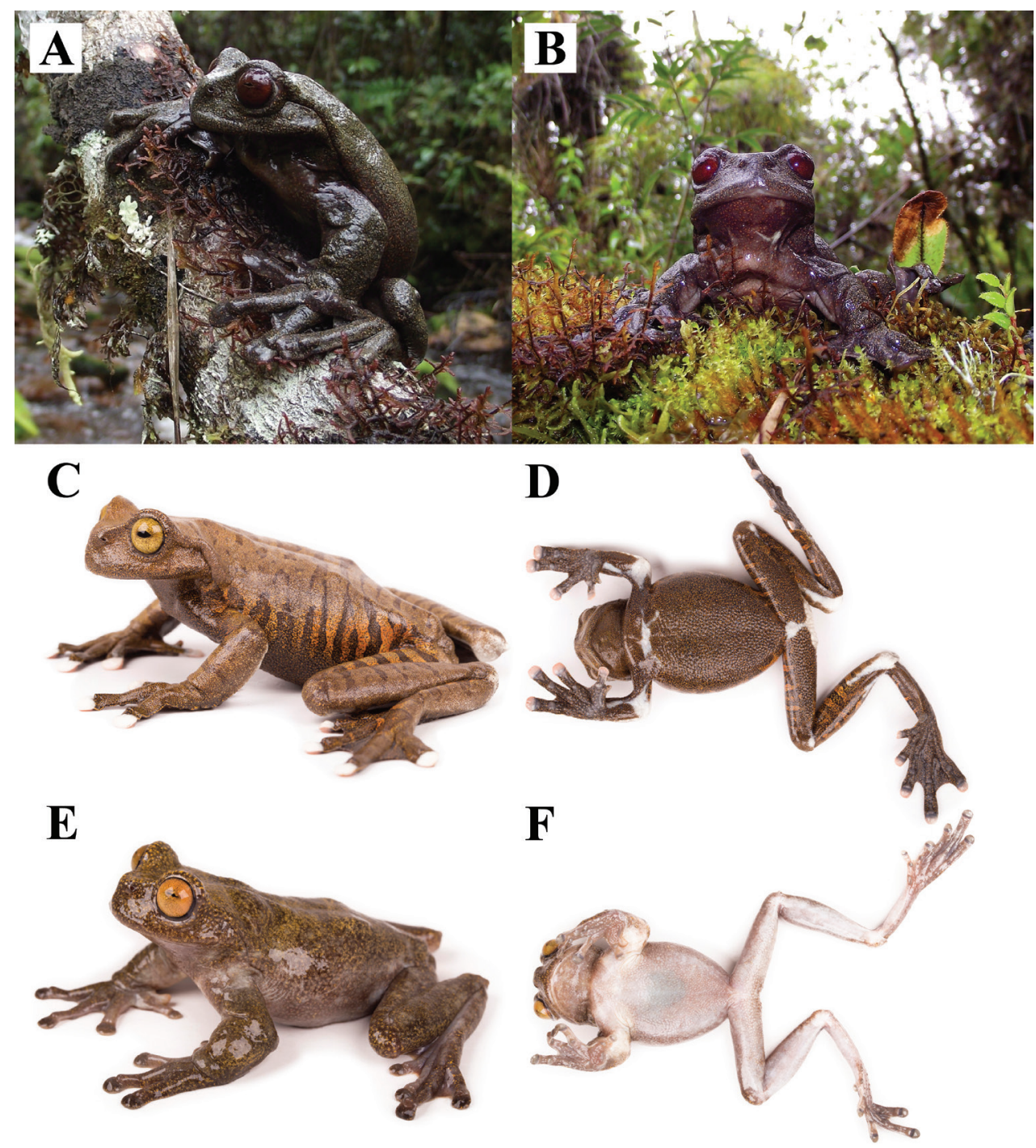

Figure 4. Live individuals of Hyloscirtus. A, B Hyloscirtus diabolus (CORBIDI 12885, adult male, holotype, SVL = $82.3 \mathrm{~mm}$ ); C, D H. tapichalaca (QCAZ 63872, adult female, SVL = $76.19 \mathrm{~mm}$ ); E, F H. condor (QCAZ 65237, adult male, SVL = 67.18 mm). Photographs: Karla García-Burneo, Diego Quirola, and Santiago Ron.

Description of the holotype. An adult female (Figs. 5-7), $65.78 \mathrm{~mm}$ SVL. Head round in dorsal view, wider than long; snout nearly truncate in lateral and dorsal views; distance from nostril to eye shorter than diameter of eye; canthus rostralis rounded; loreal region slightly concave; internarial region nearly flat; top of head slightly concave; nostrils slightly protruding anterolaterally; lips rounded, not flared; interorbital area 

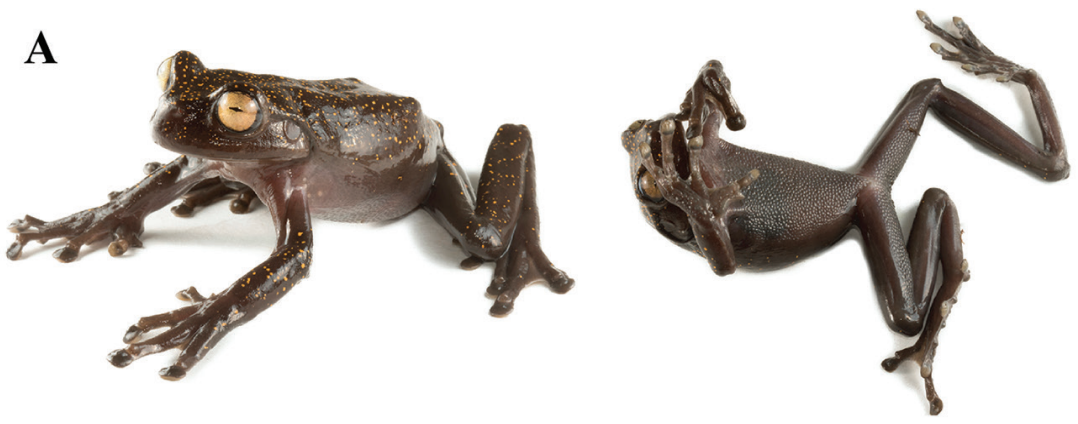

B
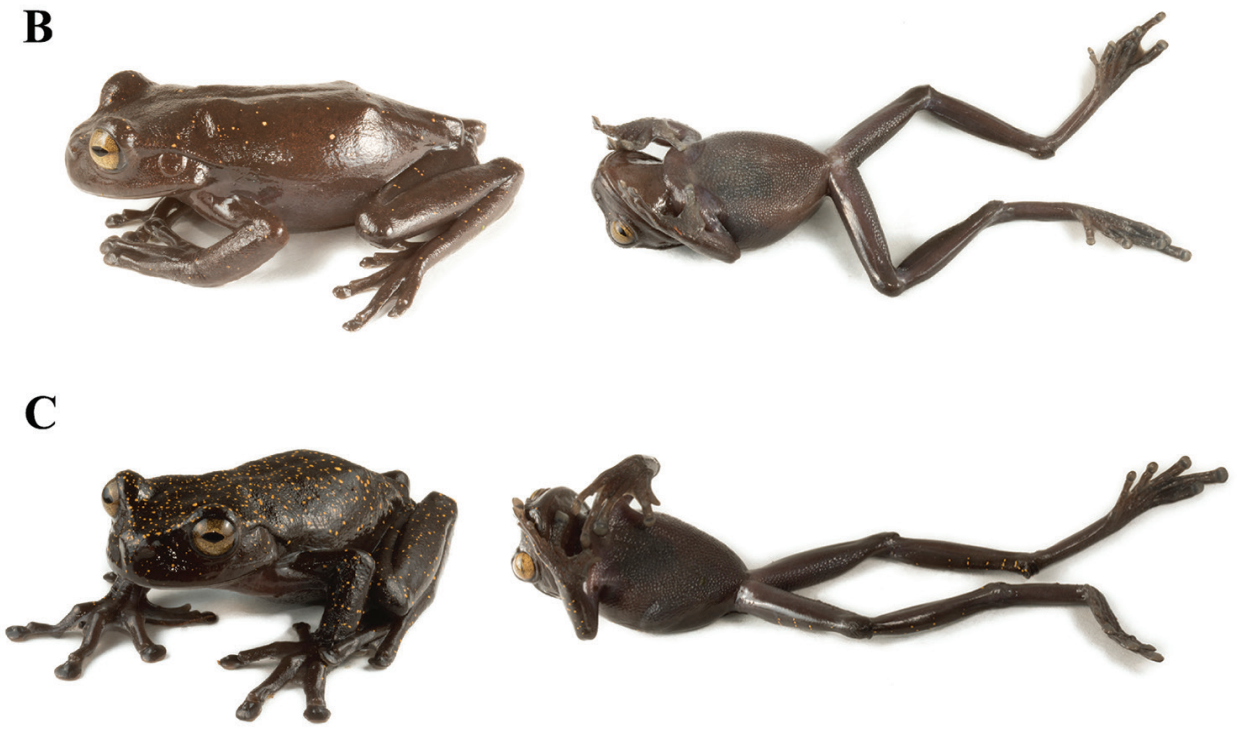

Figure 5. Variation in life of Hyloscirtus hillisi sp. n. from Reserva Biológica El Quimi. A QCAZ 68649 (adult female, holotype, $S V L=65.78 \mathrm{~mm}$ ) B QCAZ 68646 (subadult female, $S V L=48.55 \mathrm{~mm}$ ) $\mathbf{C}$ not collected.

slightly convex; eye large, protuberant; diameter of eye 1.85 times diameter of tympanic annulus; supratympanic fold thick, curved, covering posterodorsal edge of tympanum, extending from eye to posterior end of mandible and to shoulder; tympanum rounded; tympanic annulus distinct, rounded, separated from eye by ca. 1.43 times its diameter.

Forearms robust compared to upper arms but not hypertrophied; axillary membrane absent; ulnar tubercles absent; relative length of fingers I $<$ II $<$ IV $<$ III; fingers bearing large, oval discs, wider than finger; subarticular tubercles prominent, round to ovoid, single; supernumerary tubercles present, small and rounded; thenar tubercle, elliptical; palmar tubercle round; prepollical tubercle large, elliptical; prepollex enlarged, claw shaped; webbing formula of fingers I basal II2-3III21/2-2IV (Fig. 7).

Toes bearing discs broadly expanded, rounded and slightly smaller than those of fingers; relative length of toes I $<$ II $<$ III $<$ V $<$ IV; inner metatarsal tubercle large, 


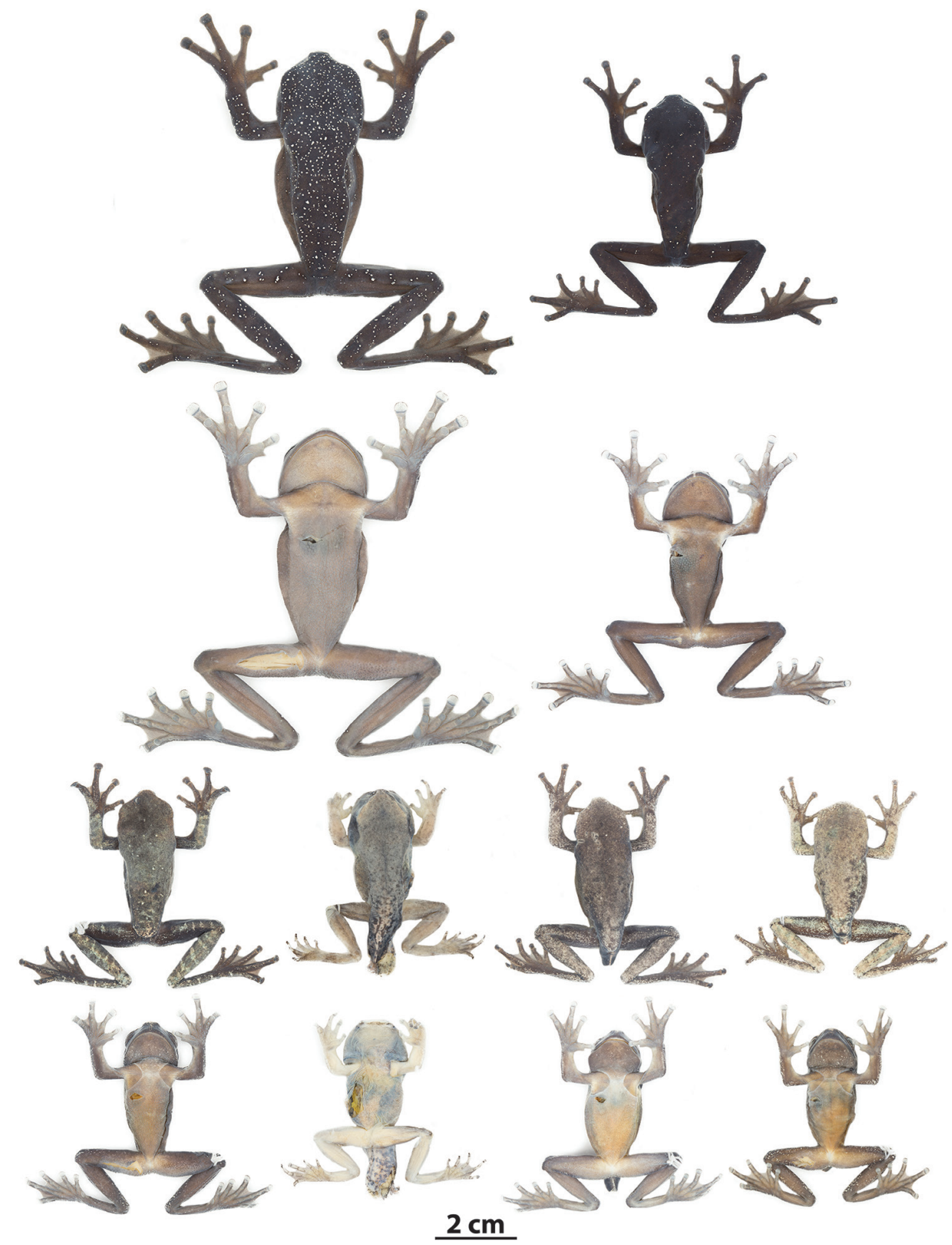

Figure 6. Variation of preserved specimens of Hyloscirtus hillisi sp. n. From left to right, first and second rows: QCAZ 68649 (holotype, adult female), QCAZ 68646 (subadult female); third and fourth rows: QCAZ 68647 (juvenile), QCAZ 69001, 68650, 68648 (metamorphs).

oval; outer metatarsal tubercle absent; subarticular tubercles single, round, large, and protuberant; supernumerary tubercles present; toes webbing formula $\mathrm{I}^{-}-2 \mathrm{III} 1^{+}-$

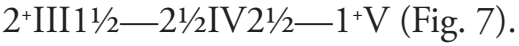




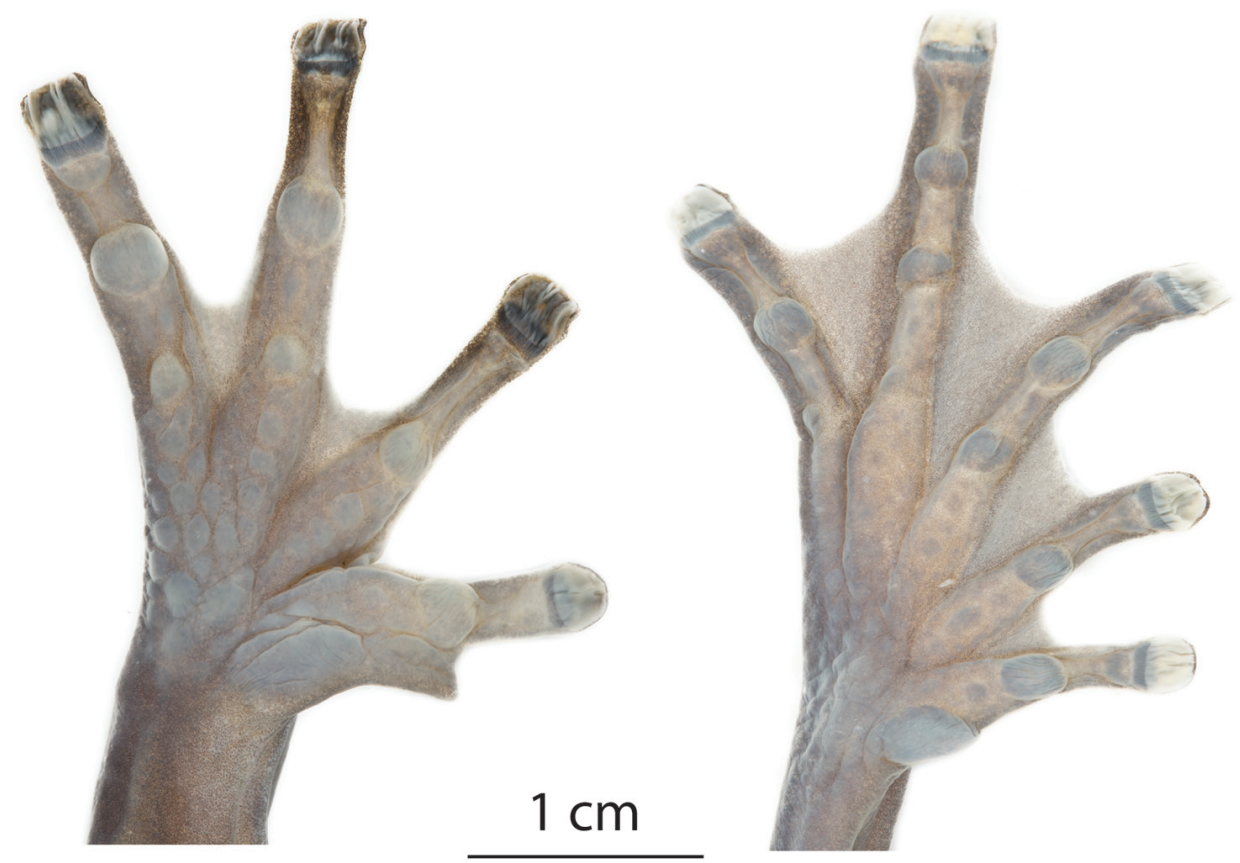

Figure 7. Ventral views of the left hand and foot of Hyloscirtus hillisi sp. n. Holotype (QCAZ 68649).

Skin on dorsum, flanks, dorsal surfaces of limbs, throat, chest, dorsal, and inner surfaces of thighs smooth; belly and ventral surfaces of thighs areolate, those of shanks smooth. Cloacal opening directed posteriorly at upper level of thighs, round tubercles below and of vent. Tongue slightly cordiform, widely attached to mouth floor; vomerine odontophores conic-shaped, separated medially, behind level of ovoid choana; each bearing 3-5 vomerine teeth. Additional measurements of the holotype are listed in Table 3.

Color of holotype in preservative. (Figure 6). Dorsal surfaces of head, body, and limbs, including fingers, dark grayish-brown densely stippled with minute, cream flecks. Ventral surfaces of limbs and belly grayish-brown, ventral surfaces of discs, webbing, chest, and throat paler.

Color of holotype in life. (Figure 5A). Based on digital photographs. Dorsal surfaces same as above except that flecks are bright orange. Ventral surfaces are dark grayishbrown. Ventral pads of digital discs on fingers and toes are gray. Iris is yellowish-cream.

Variation. Dorsal and ventral variation of preserved individuals is depicted in Figure 6. Morphometric variation is shown in Table 3. In preservative, dorsum varies from dark grayish-brown (e.g., QCAZ 68646) in adults to pale grayish-brown (e.g., QCAZ 68647, 68650) or pale gray (e.g., QCAZ 68648) in juveniles and metamorphs. Scattered minutes cream flecks can be present on dorsal surfaces (e.g., QCAZ 68646, 68647). Specimen QCAZ 68647 (juvenile) has cream transverse bars on the dorsal surfaces of the limbs (two to four on the forearm and five to seven on the thigh, shank, and foot). Ventral surfaces vary from pale grayish-brown (e.g., QCAZ 68646) to pale 
Table 3. Descriptive statistics for measurements of Hyloscirtus hillisi sp. n. Abbreviations: SVL = snoutvent length; $\mathrm{FL}=$ foot length; $\mathrm{HL}=$ head length $\mathrm{HW}=$ head width $\mathrm{ED}=$ eye diameter $\mathrm{TD}=$ tympanum diameter; $\mathrm{TL}=$ tibia length; $\mathrm{FEL}=$ femur length. All measurements in $\mathrm{mm}$.

\begin{tabular}{lcccc}
\hline & Adult female (holotype) & Adult males $(\mathbf{n}=3)$ & Subadult females $(\mathbf{n}=\mathbf{2})$ & Juveniles $(\mathbf{n}=\mathbf{1})$ \\
\hline SVL & 65.8 & $70.3 \pm 3.1(66.7-72.3)$ & $48.6-56.8$ & 40.2 \\
FL & 29.9 & $30.3 \pm 0.1(30.1-30.4)$ & $21.4-27.6$ & 17.6 \\
HL & 14.9 & $14.3 \pm 2.7(11.4-16.6)$ & $11.9-12.9$ & 9.4 \\
HW & 22.7 & $24.5 \pm 0.9(23.7-25.5)$ & $18.4-20.5$ & 13.1 \\
ED & 6.3 & $6.5 \pm 0.1(6.4-6.6)$ & $5.1-5.2$ & 5.4 \\
TD & 3.4 & $4.3 \pm 0.2(4.1-4.3)$ & $2.9-3.2$ & 2.1 \\
TL & 32.3 & $33.9 \pm 0.6(33.4-34.6)$ & $25.6-28.1$ & 21.2 \\
FEL & 35.2 & $35.9 \pm 1.7(34.3-37.7)$ & $25.7-32.36$ & 20.9 \\
\hline
\end{tabular}

brown or cream (e.g., QCAZ 68648, 68650). Coloration of webbing and discs vary from dark grayish-brown to pale grayish-brown or gray.

In life, (Figure 5), the adult specimens are very similar to the holotype except for the density of bright orange flecks (bright yellow in situ; Figure 11A) on the dorsal surfaces. Background dorsal coloration in juveniles and metamorphs (Figure 8) varies from mottled or uniformly brown (e.g., SC 59268, QCAZ 68650) to light brown (e.g., QCAZ 68648) with or without orange-brown transversal bars on the dorsal surfaces of the limbs. Ventral surfaces vary from dark grayish-brown to cream (e.g., SC 59268). Iris varies from bronze (e.g., SC 59268) to yellowish-cream (e.g., QCAZ 68648).

Tadpole description. The following description is based on a tadpole of series QCAZ 68651 in Stage 25 (Gosner 1960). The specimen was collected in a slow-moving pool along the margins of a stream (Figure 9; 3.5187S, 78.3919W; $1991 \mathrm{~m}$ ) at the type locality on 7 July 2017 . All measurements are in $\mathrm{mm}$. Total length 86.7 ; body length 29.1 (33.6\% of total length). Body ovoid and depressed; width at the level of spiracle 19.2, height at same position 14.7; head width at level of the eyes 17.9; anterior margin of snout uniformly rounded in dorsal view and sloping at level of nares in lateral view; lateral-line system evident with supraorbital, infraorbital, mandibular, angular, postorbital, dorsal body, and ventral body lines. The arrangement of the lateralline system is symmetrical; the supra and infra orbital lines begin at the tip of the snout and join behind the eye, continuing as a single longitudinal line extending along the anterior half of the tail. The dorsal lines extend along the posterior half of the dorsum until reaching the anterior edge of the tail, at the base of the upper fin. The angular line starts behind the orbit and extends longitudinally, contouring the spiracle, to the posterior end of the body, down towards the venter and ending at the base of the vent tube. The postorbital line starts behind the intersection of the supra and infraorbital lines and continues obliquely towards the venter, joining the anteroventral line. The mandibular line originates at the lateral border of the oral disc and runs obliquely until joining the anteroventral line. The posteroventral line forms a $\mathrm{V}$ whose vertex is directed towards the midposterior venter ending at the lateral edge of the venter, at the base of the spiracle. The nostrils are ovoid, not protruding and directed anterolaterally, 
A
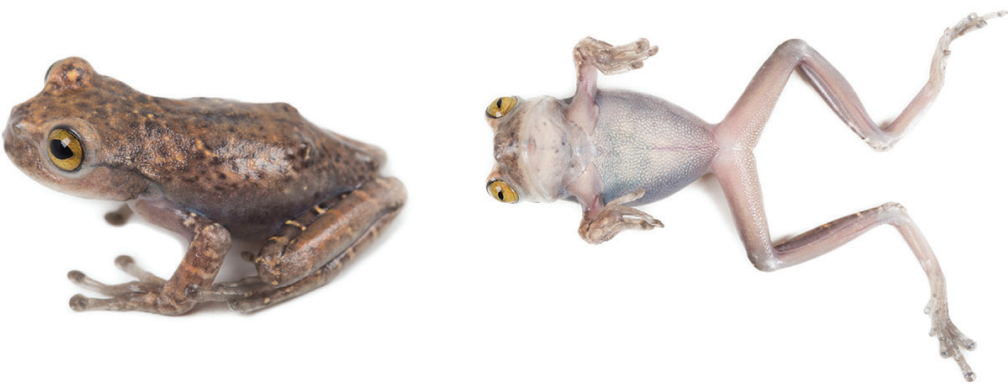

B
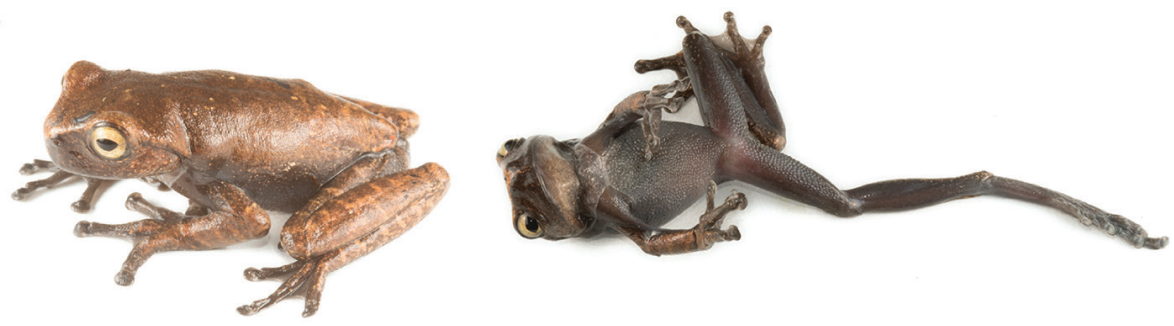

C
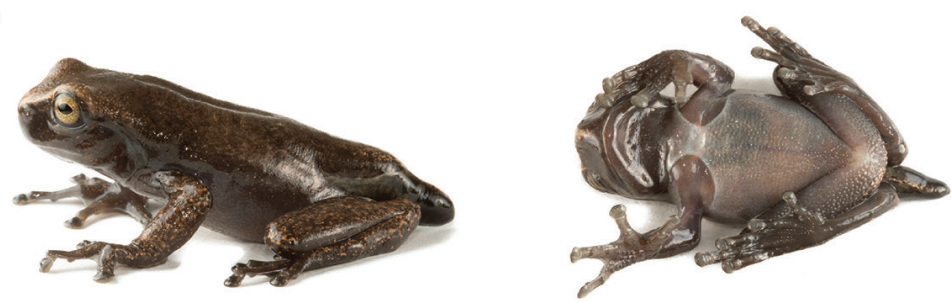

Figure 8. Color variation in life of juvenile and metamorphs of Hyloscirtus hillisi sp. n. A SC 59268 (SVL $=39.52 \mathrm{~mm}$, not preserved) B QCAZ $68648(\mathrm{SVL}=35.6 \mathrm{~mm}) \mathbf{C}$ QCAZ $68650(\mathrm{SVL}=40.73 \mathrm{~mm})$.

6.8 from tip of snout; internarial distance 8.6. Eyes positioned and directed dorsolaterally; eye length 2.8 , eye width 2.5; interorbital distance 9.9. Spiracle sinistral, located at midbody and oriented posterodorsally, inner wall free from body; tube length 2.8 , tube width 2.6; spiracular opening directed posterodorsally, diameter 1.6; distance from tip of snout to spiracular opening 22.5. Vent tube medial, opening directed posteriorly; tube length 3.8, tube width 2.6. Tail length 57.5; caudal musculature robust, narrowing gradually until tail terminus. At tail-body junction, tail muscle width 9.6, tail muscle height 11.7; maximum height of tail 17.7. Oral disc located anteroventrally; transverse width 11.6; bordered by two rows of small and rounded papillae; upper jaw sheath forming an arch, unpigmented, transverse width including lateral processes 4.0 (34.4\% of transverse width of oral disc); oral apparatus well preserved, showing complete teeth rows. Labial tooth row formula 8(8)/11(1). Only A-8 and P-1 have gaps. Tadpoles were gregarious and fled to the bottom of the pool when disturbed.

Color in preservative of tadpoles. In dorsal view, the body is gray, lighter on the tip of snout and towards the base of the tail, grayish cream belly, mouth cream; tail 


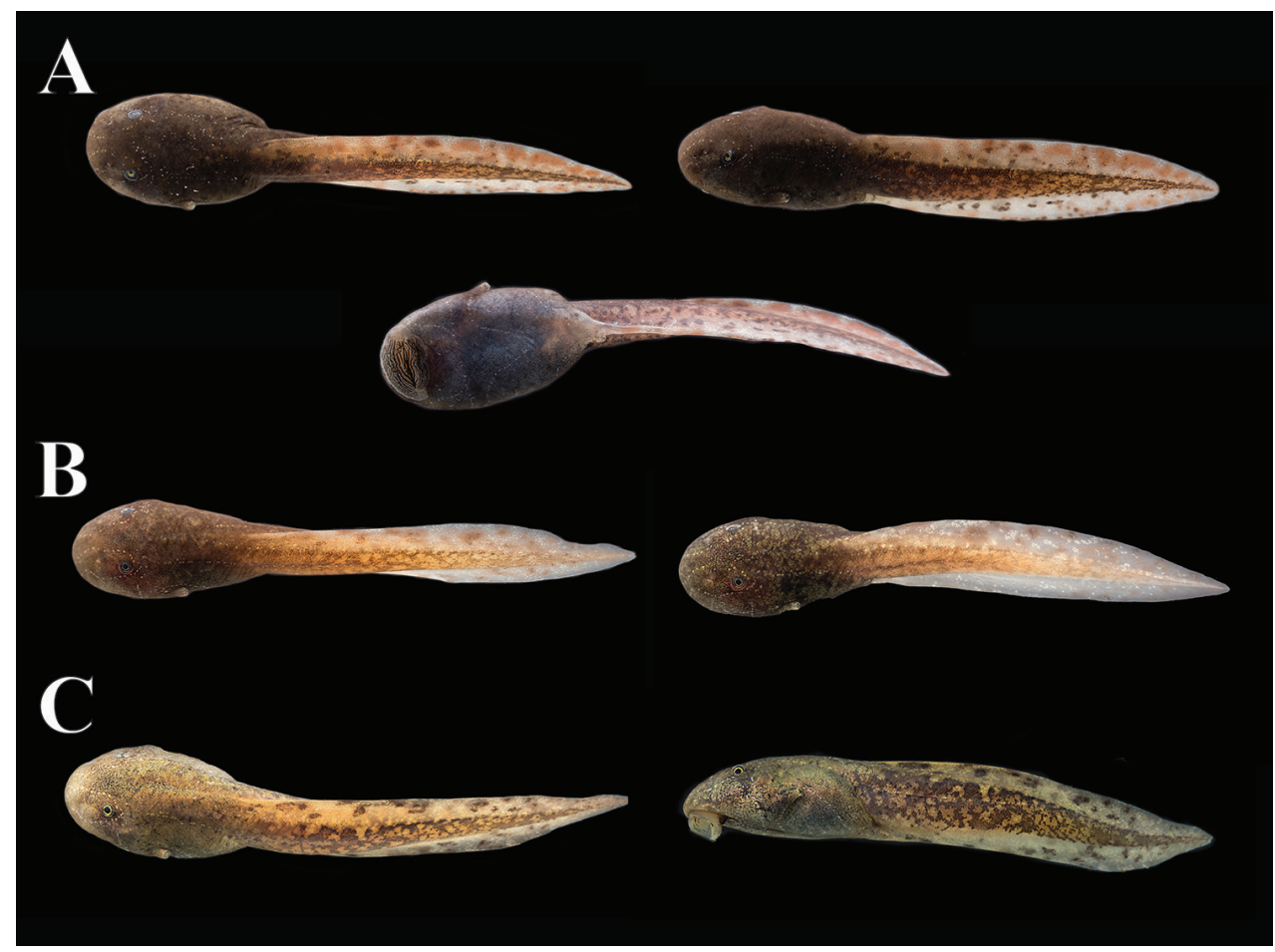

Figure 9. Variation in life of tadpoles of Hyloscirtus hillisi sp. n. A QCAZ 68651 (photograph taken 5 days after capture on 19 July 2017) B QCAZ 71182 (photograph taken 16 days after capture, on 20 July 2017) C QCAZ 71182 (photograph taken 8 months and 4 days after capture on 08 March 2018). Note change in color between (B) and (C). Gosner Stage 25. Photographs by Gustavo Pazmiño.

musculature grayish cream with irregular gray spots, upper and lower fins transparent, light gray with irregular dark gray spots.

Color in life of tadpoles. In dorsal view, body brown, including head and snout; in lateral view body dark-brown. Small bronze dots concentrate in the anterior edge of the eye, become diffuse at level of the base of the spiracle. Venter cream, becoming darker medially as result of intestines being dimly visible; oral disc light brown becoming dark brown posteriorly. Iris bronze. Vent tube cream. Muscle tail light brown with gray irregular spots; lower fin transparent cream with a combination of brown and gray irregular spots; upper fin transparent light brown with light brown spots and few scattered dark gray spots. The brown coloration and the pattern of dark gray and brown spots in several individuals is maintained; however, an individual kept in captivity (QCAZ 71182) during 8 months presents an evident change in its coloration, becoming much clearer with a combination of light brown on the back and greenish brown on the flanks; muscles of tail light brown with gray spots; lower fin cream with brown spots, upper fin greenish cream becoming transparent in the distal third with dark brown spots. The differences in coloration after 8 months in captivity may be due to the effects of diet. 


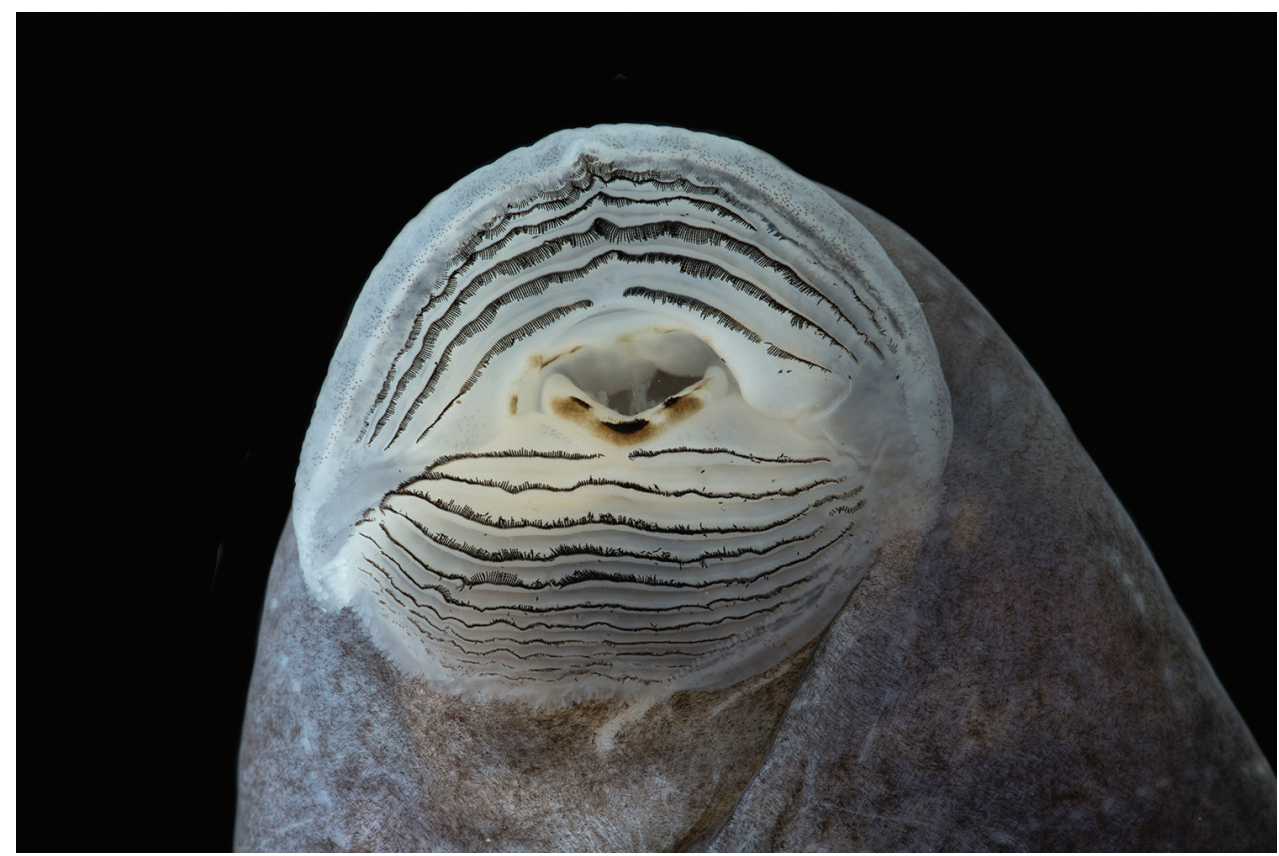

Figure 10. Oral disc of preserved tadpole of Hyloscirtus hillisi sp. n. QCAZ 68651, Gosner Stage 25. Photograph by Gustavo Pazmiño.

Tadpoles variation. Based on a series of five individuals in stage 25 and two in stages 37 and 40. Meristic variation of tadpoles in Stages 25-40 is shown in Table 4. Seven tadpoles in Stages 25-40 varied in total length, ranging from 57.4 to $101 \mathrm{~mm}$; body length ranged from 20.4 to $34.2 \mathrm{~mm}$; tail length ranged from 37.0 to $67.6 \mathrm{~mm}$. Inter orbital distance from 6.27 to $10.43 \mathrm{~mm}$. Labial tooth row formula varied from $8(8) / 11(1)$ to $7(7) / 12(1)$ (Figure 10$)$.

Etymology. The specific name is a noun in the genitive case and is a patronym for David Hillis, an evolutionary biologist who has made significant contributions to the study of the evolution of amphibians and reptiles. During the 1980s, David Hillis carried out fieldwork in Ecuador that resulted in the discovery of three undescribed species of the $H$. larinopygion group. In 1990, in collaboration with WE Duellman, he published the first phylogeny for the $H$. larinopygion group using allozyme data $(\mathrm{Du}-$ ellman and Hillis 1990). Currently he is professor at the University of Texas in Austin.

Distribution and natural history. Hyloscirtus hillisi is only known from two nearby sites (airline distance $=1.7 \mathrm{~km}$ ) on the slopes of a flattop limestone mountain in the Río Quimi basin, Provincia Zamora Chinchipe, at elevations between 1991 and 2134 $\mathrm{m}$ (Figure 2). Biogeographic region is Eastern Montane Forest according to Ron et al. (2018) classification. Vegetation at the type locality (Figure 11B, C) was dominated by shrubs ( $1.5 \mathrm{~m}$ tall) with sparse trees (10-15 $\mathrm{m}$ tall). The ground had cushioned consistency and was covered by roots and bare soil. Mosses and ground-bromeliads were abundant. This type of ground cover is locally known as bamba. Two adults and 
Table 4. Measurements (in mm) of tadpoles of Hyloscirtus hillisi sp. $\mathrm{n}$. Mean $\pm \mathrm{SD}$ is given with range in parentheses. Abbreviations: TL (total length), BL (body length), TAL (tail length), TAL/TL (ratio tail length/total length), MHT (Maximum Height of Tail, including dorsal and ventral fins), IOD (inter orbital distance), WOD (transverse width of oral disc), WUJ (transverse width of upper jaw sheath, including lateral processes), WUJ/WOD (ratio width of upper jaw sheath/width of oral disc), TUW (tube transverse width), TUL (tube length spiracle).

\begin{tabular}{lccc}
\hline Character & Stage $\mathbf{2 5}(\boldsymbol{n}=\mathbf{5})$ & Stage $\mathbf{3 7}(\boldsymbol{n}=\mathbf{1})$ & Stage $\mathbf{4 0}(\boldsymbol{n}=\mathbf{1})$ \\
\hline TL & $79.2 \pm 12.4(57.4-86.7)$ & 99.5 & 101 \\
BL & $26.1 \pm 3.6(20.4-29.1)$ & 34.2 & 33.4 \\
TAL & $53 \pm 9.02(37-58)$ & 65.3 & 67.6 \\
TAL/TL & $0.7 \pm 0.04(0.6-0.7)$ & 0.7 & 0.7 \\
MHT & $15.4 \pm 1.7(13.7-17.7)$ & 19 & 19.4 \\
IOD & $8.4 \pm 1.5(6.3-9.9)$ & 10.2 & 10.4 \\
WOD & $9.3 \pm 1.7(7-11.6)$ & 11.7 & 11.7 \\
WUJ & $3.9 \pm 0.1(3.8-4)$ & 5.2 & 5.5 \\
WUJ/WOD & $2.8 \pm 0.4(2.3-3.3)$ & 2.2 & 2.1 \\
TUW & $1.9 \pm 0.5(1.4-2.6)$ & 2.7 & 3.6 \\
TUL & $2.4 \pm 0.4(1.7-2.8)$ & 3.2 & 4.3 \\
\hline
\end{tabular}

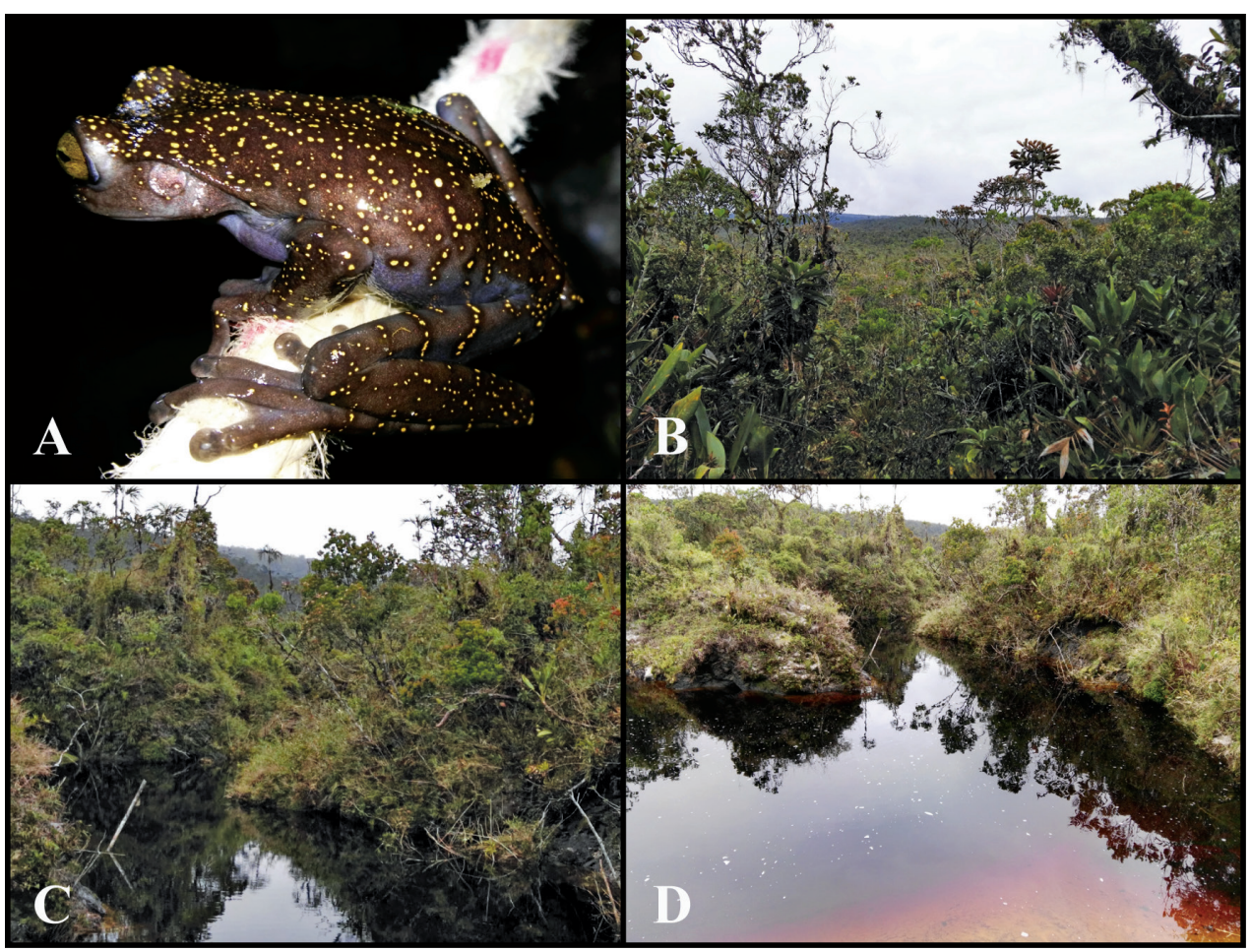

Figure I I. Habitat of Hyloscirtus hillisi sp. n. A Hyloscirtus hillisi sp. n. in situ B vegetation at the type locality, Reserva Biológica El Quimi, Ecuador $\mathbf{C}$ habitat where the adults were found $\mathbf{D}$ habitat where the tadpoles and metamorphs were found. Photographs by Diego Almeida. 
one juvenile were found on shrubs next to small streams on the Río Cristalino basin, at an elevation of $2134 \mathrm{~m}$. The tadpoles and juveniles were found in ponds on the margin of Río Cristalino, at an elevation of $1991 \mathrm{~m}$ (Figure 11D). Collections took place in July 2017 and April 2018. The site where the adults were collected is $-500 \mathrm{~m}$ from the border between Peru and Ecuador. Therefore, the occurrence of $H$. hillisi in Peru is almost certain.

Conservation status. Hyloscirtus hillisi is only known from two nearby sites in Cordillera del Cóndor. Population size is unknown, but the scant evidence suggests low abundances. In 2017, at the site where the tadpoles and juveniles were found, five hours of nocturnal search by five experienced herpetologists yielded no adults. At the site where the adults were found, ten hours of nocturnal search, for two nights, by two experienced herpetologists, yielded two adults and one subadult. Habitat destruction and fragmentation is evident at a distance of $3.5 \mathrm{~km}$ from one of the collection sites (according to Ministerio de Ambiente del Ecuador 2013 map). Cordillera del Cóndor is threatened by large and small-scale mining which has already affected amphibian populations (Valencia et al. 2017). Because of its small known distribution and nearby habitat destruction and mining activities, we suggest to assign $H$. hillisi to the Critically Endangered category under criteria B1a, b(iii), according to IUCN (2001) guidelines.

\section{Discussion}

Our phylogeny is consistent with previous phylogenies of Hyloscirtus (e.g., Almendáriz et al. 2014; Coloma et al. 2012; Faivovich et al. 2005; Rojas-Runjaic et al. 2018). The sister clade of the $H$. larinopygion group appears to be the $H$. armatus group (e.g., Rojas-Runjaic et al. 2018, Duellman et al. 2016, herein). A close relationship between the $H$. armatus group and $H$. larinopygion group is also supported by the shared presence of an enlarged prepollex protruding as a spine in the $H$. armatus group and in the Southern Clade of the H. larinopygion group. Under Duellman et al. (2016) topology, the absence of the spine in the Northern Clade would result from a secondary loss.

Hyloscirtus hillisi is the second species of the Hyloscirtus larinopygion group to be discovered in Cordillera del Cóndor, a sub-Andean mountain chain with unique geology. While the main Andes are composed of igneous and metamorphic rocks, Cordillera del Cóndor is composed predominantly by sedimentary rocks, specially limestone and sandstone (Neill 2005). Although much younger, Cordillera del Cóndor is geologically similar to the Tepuis in the Guianan region. Remarkably, surveys of the plant communities of Cordillera del Cóndor have recorded at least 10 genera that otherwise are endemic or nearly endemic to the Guianan Tepuis (Ulloa and Neill 2006).

The biogeographic affinity between the biotas of Cordillera del Cóndor and the Guianan Tepuis can be tested with phylogenies. Close relationships between biotas from El Cóndor and the Guianan Tepuis are expected under that biogeographic scenario. However, a review of recently published phylogenies is inconsistent with a Cón- 
dor-Guianan link. Our phylogeny, for example, shows that both species of Hyloscirtus from el Cóndor are closely related to Andean species from southern Ecuador and northern Peru. Similar results are evident in Pristimantis muranunka (closely related to Pristimantis from the Andes of southern Ecuador; Brito et al. 2017), Pristimantis yant$z a z a$ (closely related to Pristimantis from the Andes and adjacent Amazonian lowlands of Peru and Ecuador; Valencia et al. 2017), Excidobates condor (closely related to Excidobates from Cordillera del Cóndor and adjacent Amazonian lowlands; Almendáriz et al. 2012), Centrolene condor (sister to a large clade of Centrolene with species from the Andes of Venezuela, Colombia, Ecuador and Peru; Castroviejo-Fisher et al. 2014), and Chiasmocleis parkeri (closely related to Chiasmocleis from the Amazonian lowlands; Almendáriz et al. 2017). The combined evidence indicates that the biogeographic link between Cordillera del Cóndor and the Tepui region is not discernable in amphibians.

We suspect that the difference in biogeographic pattern observed between plants and amphibians may result from differences in the ecological factors that influence their geographic distribution. In plants, a key factor is soil type (e.g., Clark et al. 1999). The similarity in soil type between Cordillera del Cóndor and the Tepui region (Neill 2005) may explain the biogeographic connection observed in plants. In amphibians, in contrast, edaphic conditions appear to be of minor importance explaining the lack of biogeographic affinity between both regions.

As result of its historic inaccessibility, the organismal diversity of Cordillera del Cóndor is poorly known. During the last two decades, after armed conflicts between Ecuador and Peru ended, roads began to be built and biodiversity surveys became more frequent. These surveys have revealed a large number of unknown species of amphibians, several of which have been recently described (e.g., Almendáriz et al. 2014; Almendáriz et al. 2017; Almendáriz et al. 2012; Almendáriz et al. 2014; Brito et al. 2017; Brito et al. 2014; Terán-Valdez and Guayasamín 2010; Valencia et al. 2017). Additional expeditions to Cordillera del Cóndor are likely to result in more discoveries since it remains largely unexplored.

\section{Acknowledgments}

Field and laboratory work in Ecuador were funded by grants from Secretaría Nacional de Educación Superior, Ciencia, Tecnología e Innovación (SENESCYT, Arca de Noé Initiative; Omar Torres and SRR principal investigators) and PUCE-DGA (SRR principal investigator). Ana Carrillo and Claudia Terán carried out laboratory work. Fernando Rojas-Runjaic provided early access to unpublished sequences of Hyloscirtus. Gustavo Pazmiño and Valeria Chasiluisa helped making photographs of preserved specimens. Karla García-Burneo provided photographs of $H$. diabolus. For field assistance we thank María del Mar Moretta, Darwin Núñez, Kunam Nucirquia, Alex Achig, and Ricardo Gavilanes. Ministerio de Ambiente del Ecuador issued collecting permit 003-17-IC-FAU-DNB/MA. The park rangers fro Ministerio de Ambiente del Ecuador, Morona Santiago Province, provided field assistance. 


\section{References}

Almendáriz A, Brito J, Batallas D, Ron SR (2014) Una nueva especie de rana arbórea del género Hyloscirtus (Amphibia: Anura: Hylidae) de la Cordillera del Cóndor. Papeis Avulsos de Zoologia 54: 33-49. https://doi.org/10.1590/0031-1049.2014.54.04

Almendáriz A, Brito MJ, Batallas D, Vaca-Guerrero J, Ron SR (2017) Una especie nueva de rana del género Chiasmocleis (Microhylidae: Gastrophryninae) de la Cordillera del Cóndor, Ecuador. Papeis Avulsos de Zoologia 57: 119-136. https://doi.org/10.11606/00311049.2017.57.10

Almendáriz A, Ron SR, Brito J (2012) Una especie nueva de rana venenosa de altura del género Excidobates (Dendrobatoidea: Dendrobatidae) de la Cordillera del Cóndor). Papeis Avulsos de Zoologia (Sao Paulo) 52: 387-399. https://doi.org/10.1590/S003110492012021200001

Almendáriz A, Simmons JE, Brito J, Vaca-Guerrero J (2014) Overview of the herpetofauna of the unexplored Cordillera del Cóndor of Ecuador. Amphibian \& Reptile Conservation 8: 45-64.

AmphibiaWeb (2018) AmphibiaWeb: information on amphibian biology and conservation. http://amphibiaweb.org/. University of California Berkeley.

Ardila-Robayo MC, Ruiz-Carranza PM, Roa-Trujillo SH (1993) Una nueva especie de Hyla del grupo larinopygion (Amphibia: Anura: Hylidae) del sur de la Cordillera Central de Colombia. Revista de la Academia Colombiana de Ciencias Exactas, Físicas y Naturales 18: 559-566.

Brito J, Almendáriz A, Batallas D, Ron SR (2017) Nueva especie de rana bromelícola del género Pristimantis (Amphibia: Craugastoridae), meseta de la cordillera del Cóndor, Ecuador. Papeis Avulsos de Zoologia (Sao Paulo) 57: 177-195. https://doi.org/10.11606/00311049.2017.57.15

Brito J, Batallas D, Velalcázar D (2014) Nueva especie de rana terrestre del género Pristimantis (Amphiibia: Craugastoridae), meseta de la cordillera del Cóndor. Papeis Avulsos de Zoologia (Sao Paulo) 54: 435-446. https://doi.org/10.1590/0031-1049.2014.54.30

Castroviejo-Fisher S, Guayasamin JM, Gonzalez-Voyer A, Vila C (2014) Neotropical diversification seen through glassfrogs. Journal of Biogeography 41: 66-80. https://doi. org/10.1111/jbi.12208

Clark DB, Palmer MW, Clark DA (1999) Edaphic factors and the landscape-scale distributions of tropical rain forest trees. Ecology 80: 2662-2675. https://doi.org/10.1890/00129658(1999)080[2662:EFATLS]2.0.CO;2

Coloma LA, Carvajal-Endara S, Dueńas JF, Paredes-Recalde A, Morales-Mite M, AlmeidaReinoso D, Tapia EE, Hutter CR, Toral E, Guayasamín JM (2012) Molecular phylogenetics of stream frogs of the Hyloscirtus larinopygion group (Anura: Hylidae), and description of two new species from Ecuador. Zootaxa 3364: 1-78.

Darst CR, Cannatella DC (2004) Novel relationships among hyloid frogs inferred from $12 \mathrm{~S}$ and 16S mitochondrial DNA sequences. Molecular Phylogenetics and Evolution 31: 462475. https://doi.org/10.1016/j.ympev.2003.09.003

Duellman WE (1970) Hylid frogs of Middle America. Monograph of the Museum of Natural History University of Kansas 1: 1-753. 
Duellman WE, Hillis DM (1990) Systematics of frogs of the Hyla larinopygion group. Occasional Papers of the Museum of Natural History of the University of Kansas 134: 1-23.

Duellman WE, Marion AB, Hedges SB (2016) Phylogenetics, classification, and biogeography of the treefrogs (Amphibia: Anura: Arboranae). Zootaxa 4104: 1-109. https://doi. org/10.11646/zootaxa.4104.1.1

Elmer KR, Cannatella DC (2008) Three new species of leaflitter frogs from the upper Amazon forests: cryptic diversity within Pristimantis “ockendeni” (Anura: Strabomantidae) in Ecuador. Zootaxa 1784: 11-38.

Faivovich J, Garcia PC, Ananias F, Lanari L, Basso NG, Wheeler WC (2004) A molecular perspective on the phylogeny of the Hyla pulchella species group (Anura, Hylidae). Molecular Phylogenetics and Evolution 32: 938-950. https://doi.org/10.1016/j.ympev.2004.03.008

Faivovich J, Haddad CFB, Garcia PCA, Frost DR, Campbell JA, Wheeler WC (2005) Systematic review of th frog family Hylidae, with special reference to Hylinae: phylogenetic analysis and taxonomic revision. Bulletin of the American Museum of Natural History 294: 6-228. https://doi.org/10.1206/0003-0090(2005)294[0001:SROTFF]2.0.CO;2

Fouquet A, Gilles A, Vences M, Marty C, Blanc M, Gemmell NJ (2007) Underestimation of species richness in neotropical frogs revealed by mtDNA analyses. Plos Biology 2: e1109. https://doi.org/10.1371/journal.pone.0001109

Frost DR (2018) Amphibian Species of the World: an Online Reference. http://research.amnh. org/vz/herpetology/amphibia/ [accessed 06 March 2018]

Goebel AM, Donnelly MA, Atz M (1999) PCR primers and amplification methods for $12 \mathrm{~S}$ ribosomal DNA, the control region, cytochrome oxidase I, and cytochrome b in bufonids and other frogs, and an overview of PCR rimers which have amplified DNA in amphibians successfully. Molecular Phylogenetics and Evolution 11: 163-199. https://doi. org/10.1006/mpev. 1998.0538

Gosner KL (1960) A simplified table for staging anuran embryos and larvae with notes on identification. Herpetologica 16: 183-190.

Guayasamin JM, Rivera-Correa M, Arteaga A, Culebras J, Bustamante L, Pyron RA, Peñafiel N, Morochz C, Hutter CR (2015) Molecular phylogeny of stream treefrogs (Hylidae: Hyloscirtus bogotensis group), with a new species from the Andes of Ecuador. Neotropical Biodiversity 1: 2-21. https://www.doi.org/10.1080/23766808.2015.1074407

Hedges SB, Duellman WE, Heinicke MP (2008) New World direct-developing frogs (Anura: Terrana): molecular phylogeny, classification, biogeography, and conservation. Zootaxa 1737: 1-181.

Heinicke MP, Duellman WE, Hedges SB (2007) Major Caribbean and Central American frog faunas originated by ancient oceanic dispersal. Proceedings of the National Academy of Sciences of the United States of America 104: 10092-10097. https://doi.org/10.1073/ pnas.0611051104

Heinicke MP, Duellman WE, Trueb L, Means DB, MacCulloch RD, Hedges B (2009) A new frog family (Anura: Terrarana) from South America and an expanded direct-developing clade revealed by molecular phylogeny. Zootaxa 2211: 1-35.

IUCN (2001) Red list categories: version 3.1. UICN Species Survival Comission, Gland.

Janzen DH, Hallwachs W (2011) Joining inventory by parataxonomists with DNA barcoding of a large complex tropical conserved wildland in northwestern Costa Rica. PLoS One 6: e18123. 
Katoh K, Standley DM (2013) MAFFT multiple sequence alignment software version 7: improvements in performance and usability. Molecular Biology and Evolution 30: 772-780. https://doi.org/10.1093/molbev/mst010

Kearse M, Moir R, Wilson A, Stones-Havas S, Cheung M, Sturrock S, Buxton S, Cooper A, Markowitz S, Duran C, Thierer T, Ashton B, Meintjes P, Drummond A (2012) Geneious Basic: an integrated and extendable desktop software platform for the organization and analysis of sequence data. Bioinformatics 28: 1647-1649. https://doi.org/10.1093/bioinformatics/bts199

Kizirian D, Coloma LA, Paredes-Recalde A (2003) A new treefrog (Hylidae: Hyla) from southern Ecuador and a description of its antipredator behavior. Herpetologica 59: 339-349. https://doi.org/10.1655/02-41

Lanfear R, Calcott B, Ho SYW, Guindon S (2012) PartitionFinder: combined selection of partitioning schemes and substitution models for phylogenetic analyses. Molecular Biology and Evolution 29: 1695-1701. https://doi.org/10.1093/molbev/mss020

Maddison WP, Maddison DR (2018) Mesquite: a modular system for evolutionary analysis. Version 3.04. http://mesquiteproject.org [accessed June 08 2015]

Miller MA, Pfeiffer W, Schwartz T (2010) Creating the CIPRES science gateway for inference of large phylogenetic trees. 2010 Gateway Computing Environments Workshop (GCE), 8 pp. https://doi.org/10.1109/GCE.2010.5676129

Ministerio de Ambiente del Ecuador (2013) Sistema de Clasificación de los Ecosistemas del Ecuador Continental. Subsecretaría de Patrimonio Natural, Quito.

Mueses-Cisneros JJ, Anganoy-Criollo MA (2008) Una nueva especie del grupo Hyloscirtus larinopygion (Amphibia: Anura: Hylidae) del Suroccidente de Colombia. Papeis Avulsos de Zoologia (Sao Paulo) 48: 129-138. https://doi.org/10.1590/S0031-10492008001500001

Mueses-Cisneros JJ, Perdomo-Castillo IV (2011) Hyloscirtus tigrinus Mueses-Cisneros y Anganoy-Criollo, 2008: una especie amenazada, con comentarios sobre su distribución geográfica e historia natural. Herpetotropicos 5: 93-103.

Myers CW, Duellman WE (1982) A new species of Hyla from Cerro Colorado, and other tree frog records and geographical notes from Western Panama. American Museum Novitates 2752: $1-32$.

Neill D (2005) Cordillera del Cóndor: botanical treasures between the Andes and the Amazon. PlantTalk 41: 17-21.

Peters WCH (1882) Der namen der Batrachiergattung Hylonomus in Hyloscirtus zu Ändern und legte zwei neue Arten von Schlangen, Microsoma notatum und Liophis Ygraecum. Sitzungsberichte der Gesellschaft Naturforschender Freunde zu Berlin 1882: 127-129. https://doi.org/10.5962/bhl.part.15223

Rambaut A, Drummond AJ (2007) Tracer v1.4. University of Edinburgh. http://beast.bio. ed.ac.uk/Tracer

Rivera-Correa M, García-Burneo K, Grant T (2016) A new red-eyed of stream frog of Hyloscirtus (Anura: Hylidae) from Peru, with comments on the taxonomy of the genus. Zootaxa 4061: 29-40. https://doi.org/10.11646/zootaxa.4061.1.3

Rojas-Runjaic JM, Infante-Rivero EE, Salerno PE, Meza-Joya FL (2018) A new species of $H y$ loscirtus (Anura, Hylidae) from the Colombian and Venezuelan slopes of Sierra de Perijá, and the phylogenetic position of Hyloscirtus jahni (Rivero, 1961). Zootaxa 4382: 121-146. https://doi.org/10.11646/zootaxa.4382.1.4 
Ron SR, Merino-Viteri A, Ortiz DA (2018) Anfibios del Ecuador. Version 2018.0. https:// bioweb.bio/faunaweb/amphibiaweb/ [accessed March 8, 2018]

Ronquist F, Teslenko M, van der Mark P, Ayres DL, Darling A, Höhna S, Larget B, Liu L, Suchard MA, Huelsenbeck JP (2012) MrBayes 3.2: efficient bayesian phylogentic inference and model choice across a large model space. Systematic Biology 61: 539-542. https://doi.org/10.1093/sysbio/sys029

Ruiz-Carranza PM, Lynch JD (1982) Dos nuevas especies de Hyla (Amphibia: Anura) de Colombia, con aportes al conocimiento de Hyla bogotensis. Caldasia 13: 647-671.

Sambrook J, Fritsch EF, Maniatis T (1989) Molecular Cloning: a Laboratory Manual. Cold Spring Harbor Laboratory Press, New York.

Savage JM, Heyer WR (1967) Variation and distribution on the tree-frog genus Phyllomedusa in Costa Rica, Central America. Beiträge zur Neotropischen Fauna 2: 111-131. https:// doi.org/10.1080/01650526709360400

Tamura K, Peterson D, Peterson N, Stecher G, Nei M, Kumar S (2011) MEGA5: molecular evolutionary genetics analysis using maximum likelihood, evolutionary distance, and maximum parsimony methods. Molecular Biology and Evolution 28: 2731-2739. https:// doi.org/10.1093/molbev/msr121

Terán-Valdez A, Guayasamín JM (2010) The smallest terrestrial vertebrate of Ecuador: A new frog of the genus Pristimantis (Amphibia: Strabomantidae) from the Cordillera del Cóndor. Zootaxa 2447: 53-68.

Ulloa C, Neill D (2006) Phainantha shuariorum (Melastomataceae), una especie nueva de la Cordillera del Cóndor, Ecuador, disyunta de un género guayanés. Novon 16: 281-285. https://doi.org/10.3417/1055-3177(2006)16[281:PSMUEN]2.0.CO;2

Valencia JH, Dueñas MR, Székely P, Batallas D, Pulluquitín F, Ron SR (2017) A new species of direct-developing frog of the genus Pristimantis (Anura: Terrarana: Craugastoridae) from Cordillera del Cóndor, Ecuador, with comments on threats to the anuran fauna in the region. Zootaxa 4353: 447-466. https://doi.org/10.11646/zootaxa.4353.3.3

Vieites DR, Wollenberg KC, Andreone F, Kohler J, Glaw F, Vences M (2009) Vast underestimation of Madagascar's biodiversity evidenced by an integrative amphibian inventory. Proceedings of the National Academy of Sciences of the United States of America 106: 8267-8272. https://doi.org/10.1073/pnas.0810821106

Wiens JJ, Fetzner JW, Parkinson CL, Reeder TW (2005) Hylid frog phylogeny and sampling strategies for speciose clades. Systematic Biology 54: 778-807. https://doi. org/10.1080/10635150500234625

Wiens JJ, Graham CH, Moen DS, Smith SA, Reeder TW (2006) Evolutionary and ecological causes of the latitudinal diversity gradient in hylid frogs: treefrog trees unearth the roots of high tropical diversity. American Naturalist 168: 579-596. https://doi. org/10.1086/507882

Zwickl DL (2006) Genetic algorithm approaches for the phylogenetic analysis of large biological sequence dataset under the maximum likelihood criterion. PhD Thesis, University of Texas, Austin. 


\section{Appendix I}

Examined specimens. All specimens were collected in Ecuador and are deposited at the Museum of Zoology, Pontificia Universidad Católica del Ecuador (QCAZ).

\begin{tabular}{|c|c|c|c|}
\hline Species & Museum Number & Province & Locality \\
\hline Hyloscirtus condor & QCAZ 65235 & $\begin{array}{c}\text { Zamora } \\
\text { Chinchipe }\end{array}$ & $\begin{array}{c}\text { Reserva Biológica Cerro Plateado, } 2200 \mathrm{~m} ; 4.6045 \mathrm{~S}, \\
78.8227 \mathrm{~W}\end{array}$ \\
\hline H. condor & QCAZ 65236 & $\begin{array}{c}\text { Zamora } \\
\text { Chinchipe }\end{array}$ & $\begin{array}{c}\text { Reserva Biológica Cerro Plateado, } 2243 \mathrm{~m} ; 4.6044 \mathrm{~S} \text {, } \\
78.8226 \mathrm{~W}\end{array}$ \\
\hline H. condor & QCAZ 65237 & $\begin{array}{l}\text { Zamora } \\
\text { Chinchipe }\end{array}$ & $\begin{array}{c}\text { Reserva Biológica Cerro Plateado, } 2219 \text { m; 4.6044S, } \\
78.8238 \mathrm{~W}\end{array}$ \\
\hline H. condor & QCAZ 65240 & $\begin{array}{c}\text { Zamora } \\
\text { Chinchipe }\end{array}$ & $\begin{array}{c}\text { Reserva Biológica Cerro Plateado, } 2320 \mathrm{~m} \text {; 4.6050S, } \\
78.8166 \mathrm{~W}\end{array}$ \\
\hline H. condor & QCAZ 65241 & $\begin{array}{c}\text { Zamora } \\
\text { Chinchipe }\end{array}$ & $\begin{array}{c}\text { Reserva Biológica Cerro Plateado, } 2320 \mathrm{~m} \text {; 4.6050S, } \\
78.8166 \mathrm{~W}\end{array}$ \\
\hline H. criptico & QCAZ 4161 & Carchi & $\begin{array}{l}22 \mathrm{~km} \text { E Maldonado, Maldonado-Tulcán Road, } 2560 \text { m; } \\
0.8301 \mathrm{~N}, 78.0456 \mathrm{~W}\end{array}$ \\
\hline H. criptico & QCAZ 4168 & Carchi & $\begin{array}{c}22 \mathrm{~km} \text { E Maldonado, Maldonado-Tulcán Road, } 2560 \mathrm{~m} \text {; } \\
0.8301 \mathrm{~N}, 78.0456 \mathrm{~W}\end{array}$ \\
\hline H. criptico & QCAZ 4169 & Carchi & $\begin{array}{c}22 \mathrm{~km} \text { E Maldonado, Maldonado-Tulcán Road, } 2560 \text { m; } \\
0.8301 \mathrm{~N}, 78.0456 \mathrm{~W}\end{array}$ \\
\hline H. criptico & QCAZ 4170 & Carchi & $\begin{array}{c}22 \mathrm{~km} \text { E Maldonado, Maldonado-Tulcán Road, } 2560 \mathrm{~m} \text {; } \\
0.8301 \mathrm{~N}, 78.0456 \mathrm{~W}\end{array}$ \\
\hline H. criptico & QCAZ 10487 & Imbabura & Cuellaje, $1813 \mathrm{~m} ; 0.4 \mathrm{~N}, 78.525 \mathrm{~W}$ \\
\hline H. criptico & QCAZ 11989 & Carchi & $\begin{array}{c}22 \mathrm{~km} \text { E Maldonado, Maldonado-Tulcán Road, } 2560 \mathrm{~m} \text {; } \\
0.8260 \mathrm{~N}, 78.0420 \mathrm{~W}\end{array}$ \\
\hline H. criptico & QCAZ 41467 & Imbabura & Seis de Julio de Cuellaje, $2800 \mathrm{~m}$; 0.3968N, 78.5273W \\
\hline H. criptico & QCAZ 42149 & Imbabura & $\begin{array}{l}\text { Cuellaje, San Antonio, Reserva Ecológica Cotacachi Cayapas, } \\
\qquad 2720 \mathrm{~m} ; 0.4775 \mathrm{~N}, 78.5626 \mathrm{~W}\end{array}$ \\
\hline H. criptico & QCAZ 42150 & Imbabura & $\begin{array}{l}\text { Cuellaje, San Antonio, Reserva Ecológica Cotacachi Cayapas, } \\
\qquad 2720 \mathrm{~m} ; 0.4775 \mathrm{~N}, 78.5626 \mathrm{~W}\end{array}$ \\
\hline H. criptico & QCAZ 42152 & Imbabura & $\begin{array}{l}\text { Cuellaje, San Antonio, Reserva Ecológica Cotacachi Cayapas, } \\
\qquad 2720 \mathrm{~m} ; 0.4775 \mathrm{~N}, 78.5626 \mathrm{~W}\end{array}$ \\
\hline H. criptico & QCAZ 42153 & Imbabura & $\begin{array}{l}\text { Cuellaje, San Antonio, Reserva Ecológica Cotacachi Cayapas, } \\
\qquad 2720 \mathrm{~m} ; 0.4775 \mathrm{~N}, 78.5626 \mathrm{~W}\end{array}$ \\
\hline H. criptico & QCAZ 42156 & Imbabura & $\begin{array}{l}\text { Cuellaje, San Antonio, Reserva Ecológica Cotacachi Cayapas, } \\
\qquad 2720 \mathrm{~m} ; 0.4775 \mathrm{~N}, 78.5626 \mathrm{~W}\end{array}$ \\
\hline H. criptico & QCAZ 42157 & Imbabura & $\begin{array}{l}\text { Cuellaje, San Antonio, Reserva Ecológica Cotacachi Cayapas, } \\
\qquad 2720 \mathrm{~m} ; 0.4775 \mathrm{~N}, 78.5626 \mathrm{~W}\end{array}$ \\
\hline H. criptico & QCAZ 42168 & Imbabura & $\begin{array}{l}\text { Cuellaje, San Antonio, Reserva Ecológica Cotacachi Cayapas, } \\
\qquad 2720 \mathrm{~m} ; 0.4775 \mathrm{~N}, 78.5626 \mathrm{~W}\end{array}$ \\
\hline H. criptico & QCAZ 43421 & Imbabura & $\begin{array}{l}\text { Cuellaje, San Antonio, Reserva Ecológica Cotacachi Cayapas, } \\
\qquad 2560 \mathrm{~m} ; 0.4747 \mathrm{~N}, 78.5550 \mathrm{~W}\end{array}$ \\
\hline H. criptico & QCAZ 43422 & Imbabura & $\begin{array}{l}\text { Cuellaje, San Antonio, Reserva Ecológica Cotacachi Cayapas, } \\
\qquad 2560 \mathrm{~m} ; 0.4747 \mathrm{~N}, 78.5550 \mathrm{~W}\end{array}$ \\
\hline H. criptico & QCAZ 43500 & Imbabura & $\begin{array}{l}\text { Cuellaje, San Antonio, Reserva Ecológica Cotacachi Cayapas, } \\
\qquad 2794 \mathrm{~m} ; 0.4732 \mathrm{~N}, 78.5702 \mathrm{~W}\end{array}$ \\
\hline H. criptico & QCAZ 43503 & Imbabura & $\begin{array}{l}\text { Cuellaje, San Antonio, Reserva Ecológica Cotacachi Cayapas, } \\
\qquad 2830 \mathrm{~m} ; 0.4758 \mathrm{~N}, 78.5679 \mathrm{~W}\end{array}$ \\
\hline H. criptico & QCAZ 43516 & Imbabura & Cuellaje, San Antonio, 2760 m; 0.4724N, 78.5660W \\
\hline H. criptico & QCAZ 43517 & Imbabura & Cuellaje, San Antonio, 2760 m; 0.4724N, 78.5660W \\
\hline H. criptico & QCAZ 43518 & Imbabura & Cuellaje, San Antonio, 2765 m; 0.4724N, 78.5660W \\
\hline H. criptico & QCAZ 43528 & Imbabura & Cuellaje, San Antonio, 2885 m; 0.4724N, 78.5660W \\
\hline H. criptico & QCAZ 44894 & Imbabura & $\begin{array}{l}\text { Cuellaje, San Antonio, Reserva Ecológica Cotacachi Cayapas, } \\
\qquad 2720 \mathrm{~m} ; 0.4775 \mathrm{~N}, 78.5626 \mathrm{~W}\end{array}$ \\
\hline H. criptico & QCAZ 44895 & Imbabura & $\begin{array}{l}\text { Cuellaje, San Antonio, Reserva Ecológica Cotacachi Cayapas, } \\
\qquad 2720 \mathrm{~m} ; 0.4775 \mathrm{~N}, 78.5626 \mathrm{~W}\end{array}$ \\
\hline
\end{tabular}




\begin{tabular}{|c|c|c|c|}
\hline Species & Museum Number & Province & Locality \\
\hline H. criptico & QCAZ 45466 & Carchi & $\begin{array}{c}\text { Tulcán-Maldonado Road, Quebrada Centella, } 2806 \text { m; } \\
0.8179 \mathrm{~N}, 78.016 \mathrm{~W}\end{array}$ \\
\hline H. criptico & QCAZ 50320 & Imbabura & Seis de Julio de Cuellaje, $1858 \mathrm{~m}$; 0.3968N, 78.5273W \\
\hline H. criptico & QCAZ 57951 & Imbabura & $\begin{array}{l}\text { Cuellaje, San Antonio, Reserva Ecológica Cotacachi Cayapas, } \\
\qquad 2720 \mathrm{~m} ; 0.4775 \mathrm{~N}, 78.5626 \mathrm{~W}\end{array}$ \\
\hline H. criptico & QCAZ 57952 & Imbabura & $\begin{array}{l}\text { Cuellaje, San Antonio, Reserva Ecológica Cotacachi Cayapas, } \\
\qquad 2720 \mathrm{~m} ; 0.4775 \mathrm{~N}, 78.5626 \mathrm{~W}\end{array}$ \\
\hline H. larinopygion & QCAZ 29211 & Carchi & $\begin{array}{c}24 \mathrm{~km} \text { Maldonado, Tulcán Road, } 2664 \text { m; } 0.8231 \mathrm{~N} \text {, } \\
\text { 78.0253W }\end{array}$ \\
\hline H. larinopygion & QCAZ 29212 & Carchi & $\begin{array}{l}24 \text { km Maldonado, Tulcán Road, } 2664 \text { m; } 0.8231 \mathrm{~N} \text {, } \\
\text { 78.0253W }\end{array}$ \\
\hline H. larinopygion & QCAZ 38418 & Carchi & $\begin{array}{c}\text { Cerro Centella, Tulcán-Maldonado Road, } 2788 \text { m; 0.8143N, } \\
78.0149 \mathrm{~W}\end{array}$ \\
\hline H. larinopygion & QCAZ 41826 & Carchi & Cañón de Morán, 2452 m; 0.7467N, 78.1038W \\
\hline H. larinopygion & QCAZ 45462 & Carchi & $\begin{array}{l}\text { Tulcán-Tufiño-Maldonado Road, Quebrada Centella, } 2806 \text { m; } \\
\qquad 0.8179 \mathrm{~N}, 78.0160 \mathrm{~W}\end{array}$ \\
\hline H. larinopygion & QCAZ 55574 & Carchi & Morán, $2800 \mathrm{~m} ; 0.7729 \mathrm{~N}, 78.0559 \mathrm{~W}$ \\
\hline H. larinopygion & QCAZ 55575 & Carchi & Morán, $2800 \mathrm{~m} ; 0.7729 \mathrm{~N}, 78.0559 \mathrm{~W}$ \\
\hline H. lindae & QCAZ 7593 & Napo & $10 \mathrm{Km}$ E Oyacachi, $2510 \mathrm{~m} ; 0.2322 \mathrm{~S}, 78.0072 \mathrm{~W}$ \\
\hline H. lindae & QCAZ 10483 & Napo & Oyacachi, $3217 \mathrm{~m} ; 0.2128 \mathrm{~S}, 78.0876 \mathrm{~W}$ \\
\hline H. lindae & QCAZ 41232 & Napo & $\begin{array}{l}\text { Pacto Sumaco, Parque Nacional Sumaco, } 2479 \mathrm{~m} \text {; 0.5696S, } \\
\qquad 77.5941 \mathrm{~W}\end{array}$ \\
\hline H. lindae & QCAZ 41294 & Napo & Pacto Sumaco, Pabayacu, 2775 m; 0.5639S, 77.6154W \\
\hline H. lindae & QCAZ 41295 & Napo & Pacto Sumaco, Pabayacu, 2775 m; 0.5639S, 77.6154W \\
\hline H. lindae & QCAZ 41296 & Napo & Pacto Sumaco, Pabayacu, 2775 m; 0.5639S, 77.6154W \\
\hline H. lindae & QCAZ 41297 & Napo & Pacto Sumaco, Pabayacu, 2775 m; 0.5639S, 77.6154W \\
\hline H. lindae & QCAZ 41298 & Napo & Pacto Sumaco, Pabayacu, 2775 m; 0.5639S, 77.6154W \\
\hline H. lindae & QCAZ 45342 & Napo & 11-12 km E Papallacta, $2700 \mathrm{~m} ; 0.3884 S, 78.0605 \mathrm{~W}$ \\
\hline H. lindae & QCAZ 45345 & Napo & $\begin{array}{c}\text { Papallacta, Papallacta-Cuyuja Road, } 2600 \mathrm{~m} ; 0.3884 \mathrm{~S} \text {, } \\
\text { 78.0605W }\end{array}$ \\
\hline H. lindae & QCAZ 45346 & Napo & $\begin{array}{l}\text { Papallacta, Papallacta-Cuyuja Road, } 2600 \mathrm{~m} ; 0.3884 \mathrm{~S} \text {, } \\
78.0605 \mathrm{~W}\end{array}$ \\
\hline H. lindae & QCAZ 45463 & Sucumbíos & $\begin{array}{l}11 \text { km S Santa Bárbara, La Bonita Road, } 2341 \text { m; 0.6159N, } \\
\text { 77.4879W }\end{array}$ \\
\hline H. pacha & QCAZ 10489 & $\begin{array}{l}\text { Morona } \\
\text { Santiago }\end{array}$ & Gualaceo-Limón Road, 2120 m; 3.0310S, 78.5270W \\
\hline H. pacha & QCAZ 48237 & $\begin{array}{l}\text { Morona } \\
\text { Santiago }\end{array}$ & $\begin{array}{l}\text { Plan de Milagro, } 8 \text { km Plan de Milagro, } 2152 \mathrm{~m} ; 3.0011 \mathrm{~S} \text {, } \\
\text { 78.5052W }\end{array}$ \\
\hline H. pacha & QCAZ 48238 & $\begin{array}{l}\text { Morona } \\
\text { Santiago }\end{array}$ & $\begin{array}{c}\text { Plan de Milagro, } 9 \mathrm{~km} \text { Plan de Milagro, } 2300 \mathrm{~m} ; 3.0079 \mathrm{~S} \text {, } \\
\text { 78.5253W }\end{array}$ \\
\hline H. pacha & QCAZ 48239 & $\begin{array}{l}\text { Morona } \\
\text { Santiago }\end{array}$ & $\begin{array}{c}\text { Plan de Milagro, } 9 \mathrm{~km} \text { Cuenca Road, } 2300 \mathrm{~m} ; 3.0079 \mathrm{~S} \text {, } \\
78.5253 \mathrm{~W}\end{array}$ \\
\hline H. pacha & QCAZ 48240 & $\begin{array}{l}\text { Morona } \\
\text { Santiago }\end{array}$ & $\begin{array}{c}\text { Plan de Milagro, } 9 \mathrm{~km} \text { Cuenca Road, } 2300 \mathrm{~m} ; 3.0079 \mathrm{~S} \text {, } \\
78.5253 \mathrm{~W}\end{array}$ \\
\hline H. pacha & QCAZ 48241 & $\begin{array}{l}\text { Morona } \\
\text { Santiago }\end{array}$ & $\begin{array}{c}\text { Plan de Milagro, } 9 \mathrm{~km} \text { Plan de Milagro, } 2300 \mathrm{~m} ; 3.0079 \mathrm{~S} \text {, } \\
78.5253 \mathrm{~W}\end{array}$ \\
\hline H. pacha & QCAZ 57944 & $\begin{array}{l}\text { Morona } \\
\text { Santiago }\end{array}$ & Limón Indanza, 2300 m; 3.0079S, 78.5253W \\
\hline H. pantostictus & QCAZ 731 & Sucumbíos & $\begin{array}{c}3.5 \text { km Santa Bárbara-La Bonita Road, } 2690 \text { m; 0.6490N, } \\
77.5040 \mathrm{~W}\end{array}$ \\
\hline H. pantostictus & QCAZ 2721 & Sucumbíos & $\begin{array}{c}6.1 \mathrm{~km} \text { Santa Bárbara-La Bonita Road, } 2760 \mathrm{~m} ; 0.6410 \mathrm{~N}, \\
77.4989 \mathrm{~W}\end{array}$ \\
\hline H. pantostictus & QCAZ 3753 & Sucumbíos & Santa Bárbara, 2656 m; 0.6437N, 77.5257W \\
\hline H. pantostictus & QCAZ 4505 & Sucumbíos & Santa Bárbara, $2656 \mathrm{~m} ; 0.6437 \mathrm{~N}, 77.5257 \mathrm{~W}$ \\
\hline H. pantostictus & QCAZ 4506 & Sucumbíos & Santa Bárbara, 2656 m; 0.6437N, 77.5257W \\
\hline H. pantostictus & QCAZ 6596 & Sucumbíos & Santa Bárbara, $2710 \mathrm{~m} ; 0.6437 \mathrm{~N}, 77.5257 \mathrm{~W}$ \\
\hline
\end{tabular}




\begin{tabular}{|c|c|c|c|}
\hline Species & Museum Number & Province & Locality \\
\hline H. pantostictus & QCAZ 10661 & Sucumbíos & Santa Bárbara, $2700 \mathrm{~m} ; 0.64373 \mathrm{~N}, 77.5257 \mathrm{~W}$ \\
\hline H. pantostictus & QCAZ 10671 & Sucumbíos & Santa Bárbara, 2700 m; 0.6437N, 77.5257W \\
\hline H. pantostictus & QCAZ 11660 & Sucumbíos & Santa Bárbara, 2656 m; 0.6437N, 77.5257W \\
\hline H. pantostictus & QCAZ 11661 & Sucumbíos & Santa Bárbara, 2656 m; 0.6437N, 77.5257W \\
\hline H. pantostictus & QCAZ 11662 & Sucumbíos & Santa Bárbara, 2656 m; 0.6437N, 77.5257W \\
\hline H. pantostictus & QCAZ 11663 & Sucumbíos & Santa Bárbara, 2656 m; 0.6437N, 77.5257W \\
\hline H. pantostictus & QCAZ 11664 & Sucumbíos & Santa Bárbara, 2656 m; 0.6437N, 77.5257W \\
\hline H. pantostictus & QCAZ 11665 & Sucumbíos & Santa Bárbara, 2656 m; 0.6437N, 77.5257W \\
\hline H. pantostictus & QCAZ 11666 & Sucumbíos & Santa Bárbara, 2656 m; 0.6437N, 77.5257W \\
\hline H. pantostictus & QCAZ 11667 & Sucumbíos & Santa Bárbara, 2656 m; 0.6437N, 77.5257W \\
\hline H. pantostictus & QCAZ 12171 & Sucumbíos & Santa Bárbara, 2800 m; 0.6437N, 77.5257W \\
\hline H. pantostictus & QCAZ 14084 & Sucumbíos & Santa Bárbara, 2710 m; 0.6415N, 77.5218W \\
\hline H. pantostictus & QCAZ 30529 & Sucumbíos & Santa Bárbara, 2656 m; 0.6437N, 77.5257W \\
\hline H. pantostictus & QCAZ 30530 & Sucumbíos & Santa Bárbara, 2656 m; 0.6437N, 77.5257W \\
\hline H. pantostictus & QCAZ 30531 & Sucumbíos & Santa Bárbara, 2656 m; 0.6437N, 77.5257W \\
\hline H. pantostictus & QCAZ 42350 & Sucumbíos & Santa Bárbara, 2709 m; 0.6445N, 77.5228W \\
\hline H. pantostictus & QCAZ 45435 & Sucumbíos & Santa Bárbara, 2709 m; 0.6444N, 77.5522W \\
\hline H. pantostictus & QCAZ 45438 & Sucumbíos & Santa Bárbara, 2656 m; 0.6437N, 77.5257W \\
\hline H. pantostictus & QCAZ 45440 & Sucumbíos & Santa Bárbara, 2586 m; 0.6436N, 77.5323W \\
\hline H. pantostictus & QCAZ 45449 & Sucumbíos & $\begin{array}{l}\text { Santa Bárbara, Quebrada Santa Bárbara, La Bonita, } 2341 \mathrm{~m} \text {; } \\
0.6159 \mathrm{~N}, 77.4879 \mathrm{~W}\end{array}$ \\
\hline H. pantostictus & QCAZ 46587 & Sucumbíos & 3 km Santa Bárbara, 2600 m; 0.6328N, 77.5231W \\
\hline H. pantostictus & QCAZ 46588 & Sucumbíos & 3 km Santa Bárbara, 2600 m; 0.6328N, 77.5231W \\
\hline H. princecharlesi & QCAZ 41465 & Imbabura & Seis de Julio de Cuellaje, $2800 \mathrm{~m} ; 0.3968 \mathrm{~N}, 78.5273 \mathrm{~W}$ \\
\hline H. princecharlesi & QCAZ 41466 & Imbabura & Seis de Julio de Cuellaje, $2800 \mathrm{~m} ; 0.3968 \mathrm{~N}, 78.5273 \mathrm{~W}$ \\
\hline H. princecharlesi & QCAZ 42165 & Imbabura & Cuellaje, San Antonio, 2720 m; 0.4775N, 78.5626W \\
\hline H. princecharlesi & QCAZ 43654 & Imbabura & Cuellaje, San Antonio, 2760 m; 0.4724N, 78.5660W \\
\hline H. princecharlesi & QCAZ 44893 & Imbabura & $\begin{array}{l}\text { Cuellaje, San Antonio, Reserva Ecológica Cotacachi Cayapas, } \\
2794 \mathrm{~m} ; 0.4732 \mathrm{~N}, 78.5702 \mathrm{~W}\end{array}$ \\
\hline H. psarolaimus & QCAZ 13252 & Napo & $11 \mathrm{~km}$ SE Papallacta, $2800 \mathrm{~m} ; 0.3870 \mathrm{~S}, 78.0600 \mathrm{~W}$ \\
\hline H. psarolaimus & QCAZ 27049 & Sucumbíos & $\begin{array}{l}\text { Santa Bárbara, 0.8 km Julio Andrade Road, } 2600 \mathrm{~m} ; 0.6422 \mathrm{~N} \text {, } \\
77.5264 \mathrm{~W}\end{array}$ \\
\hline H. psarolaimus & QCAZ 31671 & $\begin{array}{l}\text { Morona } \\
\text { Santiago }\end{array}$ & $\begin{array}{c}\text { San Vicente, Parque Nacional Sangay, } 15 \mathrm{~km} \text { Lagunas de } \\
\text { Atillo, } 2815 \mathrm{~m} ; 2.2102 \mathrm{~S}, 78.4487 \mathrm{~W}\end{array}$ \\
\hline H. psarolaimus & QCAZ 46095 & Napo & $60 \mathrm{~km}$ E Salcedo, $2748 \mathrm{~m} ; 0.9709 S, 78.2413 \mathrm{~W}$ \\
\hline H. psarolaimus & QCAZ 46096 & Napo & $60 \mathrm{~km}$ E Salcedo, $2748 \mathrm{~m} ; 0.9709 \mathrm{~S}, 78.2413 \mathrm{~W}$ \\
\hline H. psarolaimus & QCAZ 46097 & Napo & $60 \mathrm{~km}$ E Salcedo, $2748 \mathrm{~m} ; 0.9709 \mathrm{~S}, 78.2413 \mathrm{~W}$ \\
\hline H. psarolaimus & QCAZ 46098 & Napo & $60 \mathrm{~km}$ E Salcedo, $2748 \mathrm{~m}$; 0.9709S, 78.2413W \\
\hline H. pantostictus & QCAZ 46808 & Sucumbíos & Santa Bárbara, El Corazón, 2670 m; 0.6437N, 77.5321W \\
\hline H. pantostictus & QCAZ 46811 & Sucumbíos & Santa Bárbara, 2589 m; 0.6437N, 77.5321W \\
\hline H. psarolaimus & QCAZ 46890 & Napo & Salcedo-Tena Road, km 60, 2748 m; 0.9719S, 78.2413W \\
\hline H. pantostictus & QCAZ 46894 & Sucumbíos & Santa Bárbara, 2709 m; 0.6445N, 77.5522W \\
\hline H. pantostictus & QCAZ 46896 & Sucumbíos & Santa Bárbara, 2709 m; 0.6445N, 77.5522W \\
\hline H. pantostictus & QCAZ 46929 & Sucumbíos & Santa Bárbara, 2709 m; 0.6445N, 77.5228W \\
\hline H. pantostictus & QCAZ 50358 & Sucumbíos & Santa Bárbara, 2589 m; 0.6437N, 77.5321W \\
\hline H. pantostictus & QCAZ 50389 & Sucumbíos & Santa Bárbara, 2589 m; 0.6437N, 77.5321W \\
\hline H. pantostictus & QCAZ 50390 & Sucumbíos & Santa Bárbara, 2586 m; 0.6436N, 77.5323W \\
\hline H. pantostictus & QCAZ 50415 & Sucumbíos & Santa Bárbara, 2709 m; 0.6445N, 77.5228W \\
\hline H. psarolaimus & QCAZ 66563 & Pastaza & $\begin{array}{l}\text { Reserva Comunitaria Ankaku, Parque Nacional Llanganates, } \\
2165 \mathrm{~m} ; 1.2752 \mathrm{~S}, 78.0657 \mathrm{~W}\end{array}$ \\
\hline H. psarolaimus & QCAZ 66564 & Pastaza & $\begin{array}{l}\text { Reserva Comunitaria Ankaku, Parque Nacional Llanganates, } \\
2315 \mathrm{~m} ; 1.2764 \mathrm{~S}, 78.0759 \mathrm{~W}\end{array}$ \\
\hline
\end{tabular}




\begin{tabular}{|c|c|c|c|}
\hline Species & Museum Number & Province & Locality \\
\hline H. psarolaimus & QCAZ 66565 & Pastaza & $\begin{array}{l}\text { Reserva Comunitaria Ankaku, Parque Nacional Llanganates, } \\
2334 \mathrm{~m} ; 1.2771 \mathrm{~S}, 78.0768 \mathrm{~W}\end{array}$ \\
\hline H. psarolaimus & QCAZ 66566 & Pastaza & $\begin{array}{l}\text { Reserva Comunitaria Ankaku, Parque Nacional Llanganates, } \\
2322 \mathrm{~m} ; 1.2767 \mathrm{~S}, 78.0763 \mathrm{~W}\end{array}$ \\
\hline H. psarolaimus & QCAZ 66568 & Pastaza & $\begin{array}{l}\text { Reserva Comunitaria Ankaku, Parque Nacional Llanganates, } \\
\qquad 2216 \mathrm{~m} ; 1.2770 \mathrm{~S}, 78.0698 \mathrm{~W}\end{array}$ \\
\hline H. ptychodactylus & QCAZ 46030 & Cotopaxi & Pilaló, Quebrada 2, 2500 m; 0.9424S, 78.9956W \\
\hline H. ptychodactylus & QCAZ 46031 & Cotopaxi & Pilaló, Quebrada 2, 2500 m; 0.9424S, 78.9956W \\
\hline H. staufferorum & QCAZ 3701 & Napo & Volcán Sumaco, Lago Sumaco, 2463 m; 0.5689S, 77.5948W \\
\hline H. staufferorum & QCAZ 3704 & Napo & $\begin{array}{l}\text { Codillera de Guacamayos, } 31 \mathrm{~km} \text { Baeza, Archidona Road, } \\
\qquad 2210 \mathrm{~m} ; 0.6505 \mathrm{~S}, 77.7907 \mathrm{~W}\end{array}$ \\
\hline H. staufferorum & QCAZ 3705 & Napo & Baeza, $2040 \mathrm{~m} ; 0.4634 \mathrm{~S}, 77.8915 \mathrm{~W}$ \\
\hline H. staufferorum & QCAZ 3706 & Napo & Baeza, $2040 \mathrm{~m}$; 0.4634S, 77.8915W \\
\hline H. staufferorum & QCAZ 11150 & Napo & 13.4 km S Río Cosanga, 2040 m; 0.6560S, 77.9129W \\
\hline H. staufferorum & QCAZ 36278 & Napo & Volcán Sumaco, Lago Sumaco, 2470 m; 0.5689S, 77.5948W \\
\hline H. staufferorum & QCAZ 36279 & Napo & Volcán Sumaco, Lago Sumaco, 2470 m; 0.5689S, 77.5948W \\
\hline H. staufferorum & QCAZ 45962 & Pastaza & $\begin{array}{l}\text { Reserva Comunitaria Ankaku, Río Challuwa Yacu, Parque } \\
\text { Nacional Llanganates, } 2250 \mathrm{~m} ; 1.2792 \mathrm{~S}, 78.0779 \mathrm{~W}\end{array}$ \\
\hline H. staufferorum & QCAZ 45963 & Pastaza & $\begin{array}{l}\text { Reserva Comunitaria Ankaku, Río Challuwa Yacu, Parque } \\
\text { Nacional Llanganates, } 2250 \mathrm{~m} ; 1.2792 \mathrm{~S}, 78.0779 \mathrm{~W}\end{array}$ \\
\hline H. staufferorum & QCAZ 45965 & Pastaza & $\begin{array}{l}\text { Reserva Comunitaria Ankaku, Río Challuwa Yacu, Parque } \\
\text { Nacional Llanganates, } 2250 \mathrm{~m} ; 1.2792 \mathrm{~S}, 78.0779 \mathrm{~W}\end{array}$ \\
\hline H. staufferorum & QCAZ 45966 & Pastaza & $\begin{array}{l}\text { Reserva Comunitaria Ankaku, Río Challuwa Yacu, Parque } \\
\text { Nacional Llanganates, } 2250 \mathrm{~m} ; 1.2792 \mathrm{~S}, 78.0779 \mathrm{~W}\end{array}$ \\
\hline H. staufferorum & QCAZ 45967 & Pastaza & $\begin{array}{l}\text { Reserva Comunitaria Ankaku, Río Challuwa Yacu, Parque } \\
\text { Nacional Llanganates, } 2250 \mathrm{~m} ; 1.2792 \mathrm{~S}, 78.0779 \mathrm{~W}\end{array}$ \\
\hline H. staufferorum & QCAZ 56807 & Pastaza & $\begin{array}{l}\text { Reserva Comunitaria Ankaku, Río Challuwa Yacu, Parque } \\
\text { Nacional Llanganates, } 2250 \mathrm{~m} ; 1.2792 \mathrm{~S}, 78.0779 \mathrm{~W}\end{array}$ \\
\hline H. staufferorum & QCAZ 64480 & Pastaza & $\begin{array}{l}\text { Reserva Comunitaria Ankaku, Río Challuwa Yacu, Parque } \\
\text { Nacional Llanganates, } 2250 \mathrm{~m} ; 1.2792 \mathrm{~S}, 78.0779 \mathrm{~W}\end{array}$ \\
\hline H. staufferorum & QCAZ 66567 & Pastaza & $\begin{array}{l}\text { Reserva Comunitaria Ankaku, Parque Nacional Llanganates, } \\
2434 \mathrm{~m} ; 1.2799 \mathrm{~S}, 78.0826 \mathrm{~W}\end{array}$ \\
\hline H. tapichalaca & QCAZ 15083 & $\begin{array}{c}\text { Zamora } \\
\text { Chinchipe }\end{array}$ & $\begin{array}{l}\text { Yangana-Valladolid Road, Reserva Tapichalaca, } 2625 \mathrm{~m} ; \\
\text { 4.4816S, 79.1491W }\end{array}$ \\
\hline H. tapichalaca & QCAZ 15084 & $\begin{array}{c}\text { Zamora } \\
\text { Chinchipe }\end{array}$ & $\begin{array}{l}\text { Yangana-Valladolid Road, Reserva Tapichalaca, } 2625 \mathrm{~m} ; \\
\text { 4.4816S, 79.1491W }\end{array}$ \\
\hline H. tapichalaca & QCAZ 15085 & $\begin{array}{l}\text { Zamora } \\
\text { Chinchipe }\end{array}$ & $\begin{array}{l}\text { Yangana-Valladolid Road, Reserva Tapichalaca, } 2625 \text { m; } \\
\text { 4.4816S, 79.1491W }\end{array}$ \\
\hline H. tapichalaca & QCAZ 16704 & $\begin{array}{l}\text { Zamora } \\
\text { Chinchipe }\end{array}$ & $\begin{array}{l}\text { Yangana-Valladolid Road, Reserva Tapichalaca, } 2697 \text { m; } \\
\text { 4.4816S, 79.1491W }\end{array}$ \\
\hline H. tapichalaca & QCAZ 16705 & $\begin{array}{l}\text { Zamora } \\
\text { Chinchipe }\end{array}$ & $\begin{array}{l}\text { Yangana-Valladolid Road, Reserva Tapichalaca, } 2697 \text { m; } \\
\text { 4.4816S, 79.1491W }\end{array}$ \\
\hline H. tapichalaca & QCAZ 16706 & $\begin{array}{c}\text { Zamora } \\
\text { Chinchipe }\end{array}$ & $\begin{array}{l}\text { Yangana-Valladolid Road, Reserva Tapichalaca, } 2697 \mathrm{~m} ; \\
\text { 4.4816S, 79.1491W }\end{array}$ \\
\hline H. tapichalaca & QCAZ 17776 & $\begin{array}{l}\text { Zamora } \\
\text { Chinchipe }\end{array}$ & $\begin{array}{c}\text { Yangana-Valladolid Road, Reserva Tapichalaca, } 2697 \mathrm{~m} \text {; } \\
\text { 4.4816S, 79.1491W }\end{array}$ \\
\hline H. tapichalaca & QCAZ 17777 & $\begin{array}{c}\text { Zamora } \\
\text { Chinchipe }\end{array}$ & $\begin{array}{l}\text { Yangana-Valladolid Road, Reserva Tapichalaca, } 2697 \mathrm{~m} ; \\
\text { 4.4816S, 79.1491W }\end{array}$ \\
\hline H. tapichalaca & QCAZ 46887 & $\begin{array}{l}\text { Zamora } \\
\text { Chinchipe }\end{array}$ & Reserva Tapichalaca, 1637 m; 4.4730S, 79.1930W \\
\hline H. tapichalaca & QCAZ 63872 & $\begin{array}{c}\text { Zamora } \\
\text { Chinchipe }\end{array}$ & $\begin{array}{l}\text { Parque Nacional Podocarpus, Tapichalaca, } 2605 \text { m; 4.4876S, } \\
\text { 79.1479W }\end{array}$ \\
\hline H. tigrinus & QCAZ 31550 & Sucumbíos & Santa Bárbara, El Corazón, 2620 m; 0.6437N, 77.5321W \\
\hline H. tigrinus & QCAZ 40331 & Sucumbíos & Santa Bárbara, 2638 m; 0.6437N, 77.5321W \\
\hline H. tigrinus & QCAZ 41351 & Sucumbíos & $\begin{array}{l}0.7 \text { km SW Santa Bárbara, Quebrada El Corazón, } 2638 \text { m; } \\
0.6437 \mathrm{~N}, 77.5321 \mathrm{~W}\end{array}$ \\
\hline
\end{tabular}

